\title{
Identification of a New Zinc Binding Chemotype by Fragment Screening
}

Panagiotis K. Chrysanthopoulos ${ }^{1, \#}$, Prashant Mujumdar ${ }^{1, \#, ~ L u c y ~ A . ~ W o o d s ~}{ }^{1}$, Olan Dolezal ${ }^{2}$, Bin Ren $^{2}$, Thomas S. Peat ${ }^{2, *}$ and Sally-Ann Poulsen ${ }^{1, *}$

${ }^{1}$ Griffith University, Griffith Institute for Drug Discovery, Nathan, Brisbane, Queensland 4111, Australia

${ }^{2}$ CSIRO, Biomedical Manufacturing Program, 343 Royal Parade, Parkville, Melbourne, Victoria 3052, Australia

\#Equal first authors

Email s.poulsen@griffith.edu.au, tom.peat@csiro.au 


\section{Abstract}

In this manuscript we report the discovery of a new zinc binding chemotype from screening a non-biased fragment library. Using the orthogonal fragment screening methods of native state mass spectrometry and surface plasmon resonance, two 3-unsubstituted-2,4-oxazolidinedione fragments, compounds $\mathbf{1 0}$ and $\mathbf{1 1}$, were found to have low micromolar binding affinity to the zinc metalloenzyme carbonic anhydrase II (CA II). This affinity approached that of fragment sized primary benzene sulfonamides, the classical zinc binding group found in most CA II inhibitors. Protein X-ray crystallography established that the 3-unsubstituted-2,4oxazolidinedione fragment bound to CA II via an interaction of the acidic ring nitrogen with the CA II active site zinc, as well as a hydrogen bond between the oxazolidinedione ring oxygen and the CA II protein backbone. We then synthesised a panel of fragment analogues by interchanging $\mathrm{O}, \mathrm{N}$ and $\mathrm{S}$ heteroatoms to establish structure-activity relationship (SAR) for the zinc binding capacity of oxazolidinedione, thiazolidinedione, hydantoin, thiohydantoin and rhodanine chemotypes for CA affinity, these chemotypes have not been tested for binding to CAs previously. We propose that 3-unsubstituted-2,4-oxazolidinediones are a viable starting point for the development of an alternative class of CA inhibitor to rival the classic primary sulfonamide class, wherein the medicinal chemistry pedigree has already spanned several decades. 


\section{Introduction}

Proteins that require a metal cofactor for function have gained significant traction as therapeutic targets, ${ }^{1,2}$ with the mechanism of action of a number of clinically approved drugs and investigational compounds attributed to metalloenzyme inhibition. ${ }^{3-6}$ Zinc is one of the most abundant metal cofactors in the human proteome $e^{7,8}$ and small molecule zinc metalloenzyme inhibitors usually comprise a zinc binding pharmacophore ${ }^{9}$ that interacts directly with the metal ion to block endogenous activity. ${ }^{10-12}$ The importance of zinc proteins is exemplified in recent studies that show a correlation between zinc recruitment and the complexity of eukaryotic genomes. ${ }^{13}$ There are a number of zinc binding groups (ZBGs) that have been explored in exquisite structural detail for binding to zinc metalloenzymes, these include the carboxylate, hydroxymate, sulfonamide, thiol and phosphonate functional groups. These functional groups are well represented in the ligands of zinc metalloprotein-ligand structures that have been deposited with the protein data bank (PDB) and in approved drugs targeting metalloenzymes. ${ }^{14}$ With the advent of fragment based drug discovery (FBDD) has come a new opportunity to discover alternate and novel metal binding groups by fragment screening. ${ }^{15}$ Fragment screening represents a dramatic change in the approach to drug discovery that makes use of low molecular weight small molecules (i.e. fragments) for unbiased identification of novel structural motifs that bind to proteins with high ligand efficiency. A hit fragment may be structurally elaborated to a new chemical entity with drug-like properties and functionality to improve strength and specificity of binding interactions with the target protein. Since 2005, fragment screening has resulted in more than 30 drug candidates that have entered clinical trials, with two U.S. Food and Drug Administration (FDA) approved drugs and several more compounds in advanced trials. ${ }^{16}$ The relatively short timeframe from fragment to U.S. FDA approved drugs has led to take-up of fragment screening approaches in academia, biotech and pharma. ${ }^{16}$ A combination of FBDD with metalloprotein targets has been the focus of several successful FBDD campaigns 
by Cohen and colleagues utilising fragment libraries assembled from pharmacophores that have a known predilection toward metal binding. ${ }^{12,17,18}$ Additionally, Klebe and colleagues have characterised the structure of a number of alternate ZBGs for carbonic anhydrase II (CA II, EC 4.2.1.1). ${ }^{19}$

Our group is interested in modulating carbonic anhydrase (CA) activity for therapeutic purposes and has previously targeted inhibition of this zinc metalloenzyme using both standard and novel medicinal chemistry strategies. ${ }^{20-24}$ hCAs $(\mathrm{h}=$ human) regulate $\mathrm{pH}$ homeostasis by catalysing the reversible hydration of carbon dioxide to bicarbonate and a proton: $\mathrm{CO}_{2}+\mathrm{H}_{2} \mathrm{O} \leftrightarrows \mathrm{HCO}_{3}{ }^{-}+$ $\mathrm{H}^{+}$and evidence is mounting that modulating tumour cell $\mathrm{pH}$ homeostasis may prove an effective anti-tumour strategy. ${ }^{24-26}$ The CA active site zinc coordinates to the imidazole sidechain of three histidine residues and to the $\mathrm{H}_{2} \mathrm{O}$ molecule involved in the $\mathrm{CO}_{2}$ hydration reaction, hence the implied target of small molecule $\mathrm{CA}$ inhibitors is the $\mathrm{CA}$ active site zinc. $\mathrm{A}$ key focus of our novel CA targeting strategies has been the discovery of new chemical entities as these are critical for the drug discovery pipeline to deliver new CA-based therapeutics. ${ }^{27} \mathrm{We}$ recently reported two novel sulfonamide compounds, the natural product Psammaplin C (1) ${ }^{28}$ and the saccharin glycoconjugate (2), ${ }^{22}$ as potent, isozyme selective inhibitors of CAs, Figure $1 \mathrm{~A}$.

More recently we reported the findings of an unbiased fragment screening campaign targeting CA II. ${ }^{29}$ Seven fragment hits (3-9) were identified, including the known ZBGs of primary sulfonamide (fragment 3) and carboxylate (fragments 4-6), Figure 1B. ${ }^{29-33}$ More interesting however was the finding of two 5-substituted tetrazoles (fragments 7 and 8 ) and a 3-substituted1,2,4-triazole (fragment 9) as hits, Figure 1B. Fragments 7-9 are not classic acidic functional groups like carboxylates and sulfonamides, but instead may be considered as acidic 
heterocycles. Additionally these heterocycles were not previously known as CA II binding chemotypes, ZBGs or metal binding groups generally. The primary sulfonamide fragment $\mathbf{3}$ displayed strongest CA II binding $\left(\mathrm{K}_{\mathrm{D}}=1.4 \mu \mathrm{M}\right)$ while fragments 4-9 were much weaker binders $\left(K_{D}\right.$ range $\left.631-1280 \mu \mathrm{M}\right) .{ }^{29}$ The strong binding affinity of the primary sulfonamide functional group for CA II compared to other known ZBGs is attributed to two key hydrogen bonds with the active site threonine residue, that are in addition to the zinc-sulfonamide interaction, Figure 2. This binding pose has been observed for $>200$ sulfonamide:CA II complexes reported in the PDB. The specificity of the two key hydrogen bonds ensures that the sulfonamide $\mathrm{ZBG}$ has very high selectivity for $\mathrm{CA}$ with minimal binding to other zinc metalloenzymes. ${ }^{34}$ Using X-ray crystallography we showed that the carboxylate and tetrazole moieties of fragments 4-8 interact with the active site zinc of CA II (either directly or via an intervening water molecule), some also formed interactions to the active site residues Thr199, Thr200 (both backbone and side chains). We were unable to obtain a crystal structure of CA II bound to triazole fragment 9 .

In this manuscript we report the discovery of a new zinc binding chemotype that was detected by fragment screening of an unbiased fragment library against CA II. We show that the 3unsubstituted-2,4-oxazolidinedione fragment, not previously known for zinc binding, exhibits particularly strong binding affinity for CA II that approaches that of the primary sulfonamide ZBG of classical CA inhibitors. We have defined the structural basis for the strong binding and have detailed structure-activity relationship (SAR) boundaries for the oxazolidinedione and related chemotypes for CA affinity using a combination of chemical design and synthesis to prepare fragment analogues followed by biophysical characterisation of new fragment analogues with native state mass spectrometry (MS), surface plasmon resonance (SPR) and protein X-ray crystallography (XRC). We have utilised MS for qualitative, semi-quantitative 
and quantitative fragment screening and to evaluate fragment SAR, known as "SAR by MS". 35 The discovery of the 3-unsubstituted-2,4-oxazolidinedione fragment as a new ZBG contributes to the growing importance of small molecule CA inhibitors that comprise non-classical features, as well as alternate and novel ZBGs for drug development generally.

A.
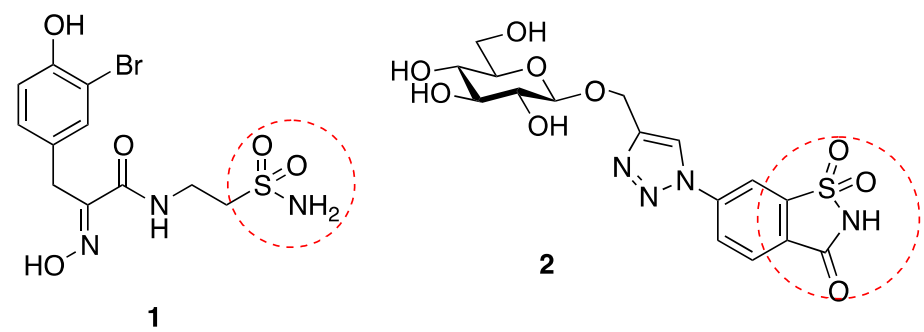

B.

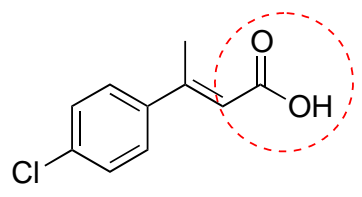

$K_{D}=905 \quad M$

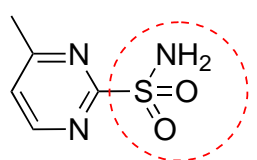

3

$\mathrm{K}_{\mathrm{D}}=1.4 \mathrm{M}$<smiles>O=C(O)c1cccc(Oc2ccccc2)c1</smiles>

5

$\mathrm{K}_{\mathrm{D}}=1280 \mathrm{M}$

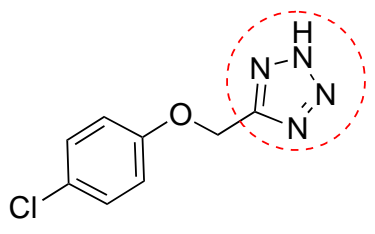

$K_{D}=709 \quad M$

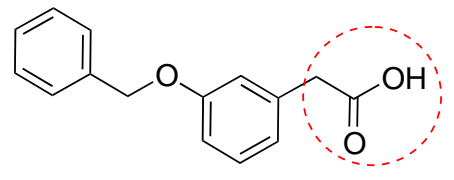

6

$K_{D}=1080 \quad M$

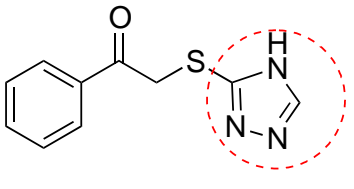

$K_{D}=194 \quad M$

Figure 1. A) Unusual carbonic anhydrase (CA) inhibitors Psammaplin $\mathrm{C}(\mathbf{1})^{28}$ and saccharin glycoconjugate (2) ${ }^{22}$. B) Fragment hits (3-9) identified from an unbiased fragment screening campaign targeting CA II. ${ }^{29}$ The known or probable zinc binding group of each fragment is circled. 


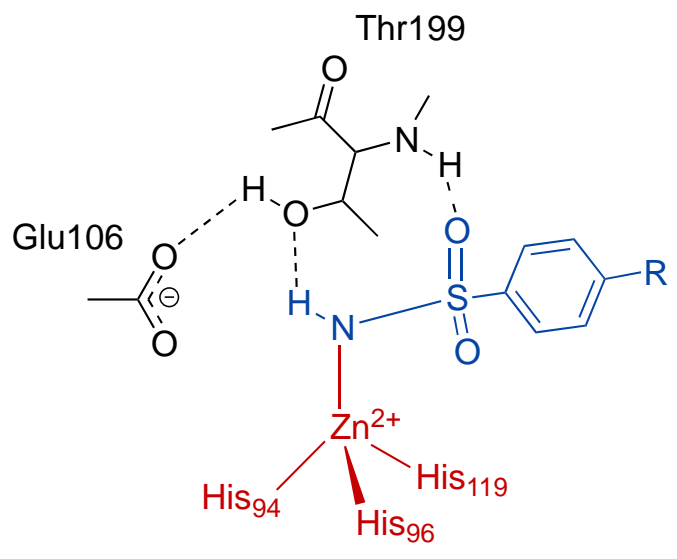

Figure 2. Common binding pose observed for $>200$ primary sulfonamide:CA II complexes reported in the Protein Data Bank. ${ }^{36}$

\section{Results and Discussion}

1-Phenyl-2,4-oxazolidinedione $\mathbf{1 0}$ and 1-(2',4'-dimethoxyphenyl)-2,4-oxazolidinedione 11, were identified and validated as binders for hCA II by fragment screening of a non-biased synthetic fragment library using orthogonal fragment screening techniques: SPR and native state mass spectrometry, Figure 3A. The binding affinities $\left(\mathrm{K}_{\mathrm{D}}\right)$ of $\mathbf{1 0}$ and $\mathbf{1 1}$ for hCA II are 3.5 $\mu \mathrm{M}$ and $6.1 \mu \mathrm{M}$, respectively, as determined by SPR. These affinities are 2-3 orders of magnitude stronger than that for the non-sulfonamide fragments 4-9 $\left(K_{D}\right.$ range $\left.631-1280 \mu \mathrm{M}\right)$, and similar to that of the sulfonamide fragment $3\left(K_{D}=1.4 \mu \mathrm{M}\right)$, reported by us recently. ${ }^{29} \mathrm{We}$ were keen to investigate the structural basis of the strong binding of $\mathbf{1 0}$ and $\mathbf{1 1}$ to hCA II and to establish if the 3-unsubstituted-2,4-oxazolidinedione heterocycle is a viable starting point for the development of a new class of $\mathrm{CA}$ inhibitor to rival the classic primary sulfonamide chemotype, wherein the medicinal chemistry pedigree has already spanned several decades. We determined the protein X-ray crystal structure of fragments $\mathbf{1 0}$ and $\mathbf{1 1}$ bound to hCA II, Figure 3B. The fragments bound via an interaction of the acidic ring nitrogen with the hCA II active site zinc. The $\mathrm{pK}_{\mathrm{a}}$ value for the $-\mathrm{NH}-$ of $\mathbf{1 0}\left(\mathrm{pK}_{\mathrm{a}}\right.$ of 5.5) together with the $\mathrm{pK}_{\mathrm{a}}$ values of a series 
of phenyl and benzyl substituted five membered heterocycles predicted to be acidic bioisosteres were measured more than 25 years ago to acquire data for the calculated Log P (cLog P) database, Pomona College MedChem CLOGP. ${ }^{37}$ The hCA II:10 and hCA II:11 structures are consistent with the prediction that 3-unsubstituted-2,4-oxazolidinedione is an acidic bioisostere. ${ }^{37}$ In addition to the zinc binding interaction there is a hydrogen bond (2.9-3.0 $\mathrm{A}$ ) formed between the ring - $\mathrm{O}-$ of $\mathbf{1 0}$ and $\mathbf{1 1}$ with the Thr199 backbone nitrogen, akin to the primary sulfonamide binding pose, this hydrogen bond likely accounts for the increased binding affinity.

We next searched the PDB against the 3-unsubstituted-2,4-oxazolidinedione fragment and identified only one protein:ligand crystal structure where the ligand comprises this fragment, the ligand is $(5 R)-5-(3-\{[3-(5-m e t h o x y b e n z i s o x a z o l-3-y l) b e n z i m i d a z o l-1-y l]$ methyl $\}$ phenyl)5-methyloxazolidinedione (12, Figure 3A) in complex with the peroxisome proliferatoractivated receptor $\gamma$ subtype $(\gamma \mathrm{PPAR}) .{ }^{38} \gamma \mathrm{PPAR}$ is involved in regulating glucose metabolism and insulin sensitivity, and $\gamma$ PPAR modulation has potential for development of treatment of type 2 diabetes mellitus. ${ }^{38}$ The oxazolidinedione moiety of $\mathbf{1 2}$ was incorporated as a replacement for a phenoxycarboxylic acid group of a lead compound series. The structure of the $\gamma$ PPAR:12 complex (PDB ID 3TY0) indicates there are hydrogen bond interactions of the oxazolidinedione to the Ser342 backbone nitrogen and the His266 side chain nitrogen of $\gamma$ PPAR. Notably $\gamma$ PPAR is not a metalloprotein hence there is no opportunity for a metal binding interaction in this protein. ${ }^{38}$ The finding that $\mathbf{1 0}$ and $\mathbf{1 1}$ bind to the hCA II active site zinc coupled with the lack of exemplar 3-unsubstituted-2,4-oxazolidinedione fragments as a ZBG in the PDB establishes the 3-unsubstituted-2,4-oxazolidinedione as a new zinc binding chemotype. 
A.<smiles>O=C1NC(=O)C(c2ccccc2)O1</smiles>

10<smiles>COc1ccc(C2OC(=O)NC2=O)c(OC)c1</smiles>

11<smiles>COc1ccc2c(-n3c(=O)n(Cc4cccc([C@H]5OC(=O)NC5=O)c4)c4ccccc43)noc2c1</smiles>

12

B.

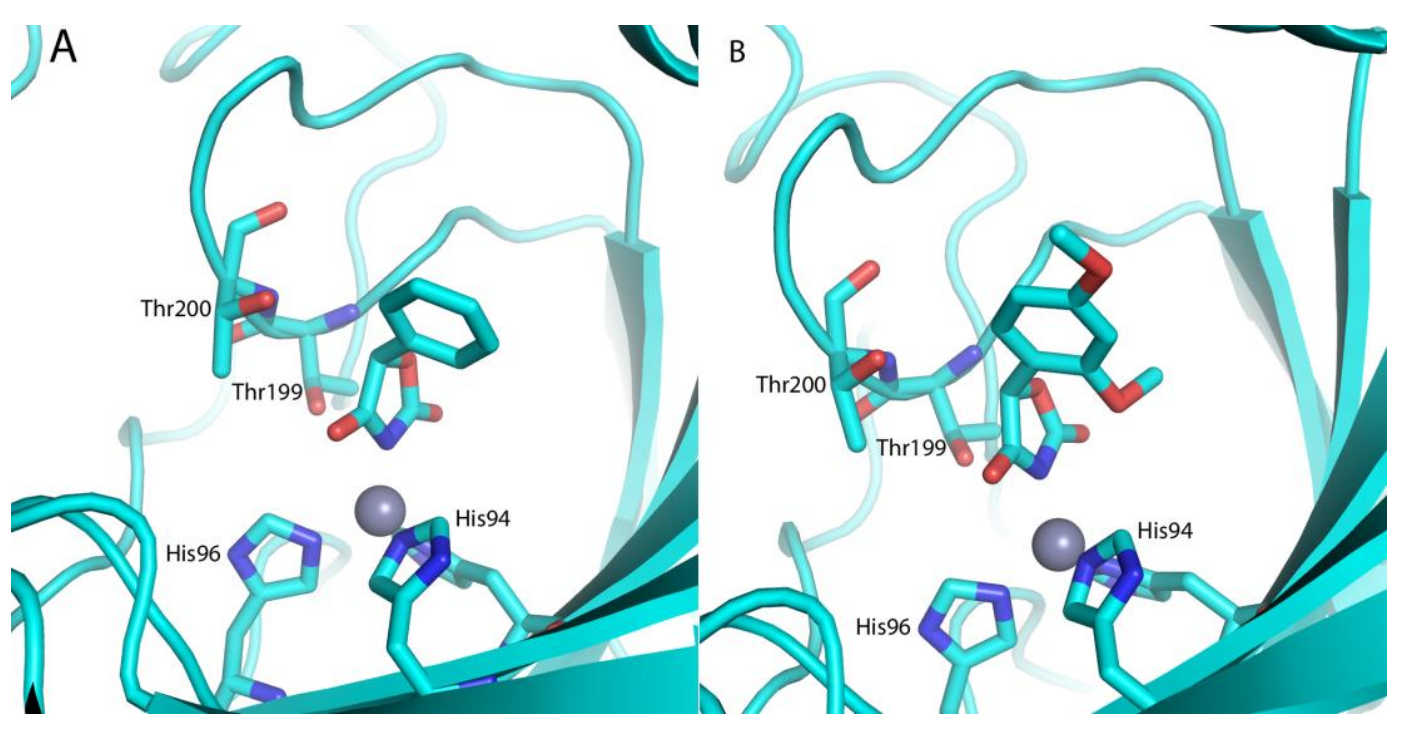

Figure 3. (A) 3-Unsubstituted-2,4-oxazolidinediones 10, 11 (this study) and $\gamma$ PPAR inhibitor 12. ${ }^{38}$ (B) Crystal structures of $\mathbf{1 0}$ and $\mathbf{1 1}$ with carbonic anhydrase II (CA II). In panel A, $\mathbf{1 0}$ is shown in the crystal structure with the zinc atom represented by a grey sphere and active site residues labelled (His94, His96, Thr199, Thr200; His119 is hidden behind the zinc and His94). In panel $\mathrm{B}, \mathbf{1 1}$ is shown in approximately the same orientation as $\mathbf{1 0}$, with the same active site residues labelled as in panel A.

\section{Compound design to establish SAR}


To ascertain the structure-activity relationships (SAR) for binding of the oxazolidinedione fragment to CAs, a series of structural modifications were made to the heteroatoms and to the 5-substituent with the acidic cyclic imide NH group retained in all compounds. The SAR fragment library comprised lead fragments $\mathbf{1 0}$ and $\mathbf{1 1}$ (Figure 3) and new fragments $\mathbf{1 3}$ - 29, Figure 4. Specifically, the replacement of the ring heteroatom from -O- (oxazolidinediones, $\mathbf{1 0}$ and 11) to either a $-\mathrm{S}-$ (thiazolidinediones, $13,14,16$ and 17) or- $\mathrm{NH}-$ (hydantoins, 15, 18, 19 , 20 and 21) was examined to determine the effect of both hydrogen bond acceptor strength ($\mathrm{O}-$ versus $-\mathrm{S}-$ ) and modification of a hydrogen bond acceptor to a hydrogen bond donor $(-\mathrm{O}-$ and $-\mathrm{S}-$ versus $-\mathrm{NH}-$ ), noting the key role of the ring oxygen in the 10: $\mathrm{CA}$ II and 11:CA II crystal structures as a hydrogen bond acceptor $(\sim 3.0 \AA$ to Thr199 N). We also modified both the ring heteroatom from $-\mathrm{O}-$ to $-\mathrm{NH}-$ (hydrogen bond acceptor to hydrogen bond donor) together with one of the carbonyls to a thiocarbonyl (thiohydantoins, 26 and 27). Depending on ease of synthesis, these heteroatom changes were combined with modification of the 5substituent (phenyl, benzyl or benzylidene derivatives) with or without added methoxy electron withdrawing groups. Additionally, the replacement of both the $-\mathrm{O}-$ heteroatom and the 4carbonyl oxygen with sulfur atoms denotes the rhodanine heterocycle (rhodanines, 22, 23, 24 and $\mathbf{2 5}$ ), which has further altered hydrogen bonding capacity compared to $\mathbf{1 0}$ and $\mathbf{1 1}$. To the best of our knowledge the thiazolidinedione, hydantoin, thiohydantoin and rhodanine chemotypes have not been tested for binding to or inhibition of CAs and will be useful to establish SAR. Finally, we included two FDA approved fragment-sized oxazolidinediones, the anticonvulsant trimethadione $\mathbf{2 8}$ and its demethylated metabolite dimethadione 29, Figure 4, in the SAR fragment library. The final assembled fragment library to establish SAR thus comprised 19 fragments $(\mathbf{1 0}, \mathbf{1 1}, \mathbf{1 3}-\mathbf{2 9})$ of molecular weight <300 Da. 


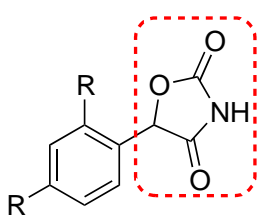

10, $\mathrm{R}=\mathrm{H}$

11, $\mathrm{R}=\mathrm{OMe}$

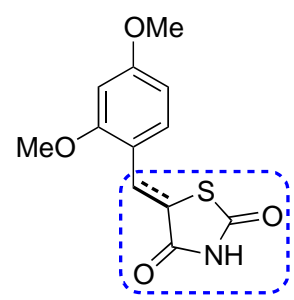

16 and 17

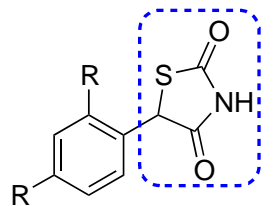

13, $\mathrm{R}=\mathrm{H}$

14, $\mathrm{R}=\mathrm{OMe}$



18 and $20, \mathrm{R}=\mathrm{H}$

19 and $21, \mathrm{R}=\mathrm{OMe}$



14

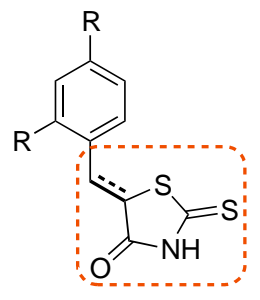

22 and $24, \mathrm{R}=\mathrm{H}$ 23 and $25, \mathrm{R}=\mathrm{OMe}$

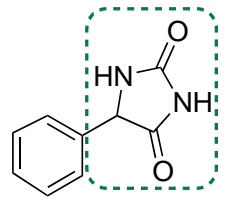

15<smiles>COc1cccc(/C=c2\[nH]c(=S)[nH]\c2=C\C2CC3CCCC2C3)c1OC</smiles>

26 and 27

$$
\begin{array}{ll}
\text { - - } & \text { oxazolidinedione } \\
- \text { - - } & \text { thiazolidinedione } \\
-- & \text { 2-thioxo-1,3-oxazolidin-4-one } \\
-- & \text { hydantoin } \\
-- & \text { rhodanine } \\
-- & \text { thiohydantoin } \\
& \text { double bond }(16,18,19,22,23 \text { and } 26) \\
\text {-. } & \text { and }
\end{array}
$$

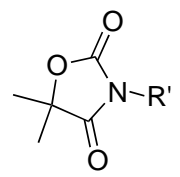

28, $\mathrm{R}^{\prime}=\mathrm{CH}_{3}$

29, $R^{\prime}=\mathrm{H}$

Figure 4. New fragment library members 13-29, selected to establish SAR around the oxazolidinedione ZBG chemotype for CA inhibition. The structure of $\mathbf{1 4}$ was revised to 14' following X-ray crystallography.

\section{Compound Screening}

In a recent fragment screening study we reported on the suitability of native state nanoelectrospray ionization mass spectrometry (nanoESI-MS) for fragment screening, highlighting numerous favourable attributes of the method including the ability to readily detect protein-ligand noncovalent complexes where $\mathrm{K}_{\mathrm{DS}}$ were in the $\mathrm{mM}$ range. ${ }^{29}$ This fragment screening method consumed minimal protein, did not utilise excess fragment concentrations and provided rapid results. There was also very good overlap with hits identified using SPR (as 
the primary screen) and X-ray crystallography (to determine fragment hit binding pose). ${ }^{29}$ Native state mass spectrometry has been applied to the study of noncovalent protein-ligand interactions for the measurement of $\mathrm{K}_{\mathrm{D}}$ values, ${ }^{39,40}$ there are however few examples of mass spectrometry for fragment screening, ${ }^{29,41-45}$ and mass spectrometry is not yet fully evaluated as a primary fragment screening method. In the present study, screening of the new fragment library members 13-29 and previously identified hit fragments $\mathbf{1 0}$ and $\mathbf{1 1}$, was carried out first using native state mass spectrometry, followed by SPR for validation. Finally X-ray crystallography was employed to provide a detailed analysis of protein-fragment interactions for validated hits.

Nanoelectrospray ionization (nanoESI) mass spectra were acquired with test samples comprising CA II with one equivalent of added fragment $(\mathbf{1 0}, \mathbf{1 1}, \mathbf{1 3}-\mathbf{2 9})$. Nine fragments were observed bound to CA II - 10, 11, 13, 14 (revised to 14' following X-ray crystallography), 17, 22, 24, 25 and 27 (revised to a mixture of $27 / 27^{\prime}$ following X-ray crystallography). The observation of [protein + fragment] complex in the nanoESI mass spectrum enables qualitative classification of a fragment as a hit (or "binder") or non-hit (or "non-binder"), with arbitrary thresholds possible to further delineate fragment binding as strong, medium or weak. To incorporate quantification to the nanoESI method we introduce here the concept of mass spectrometry fragment affinity $\left(\mathrm{FA}_{M S}\right)$, specifically we assess the potential of the $\mathrm{FA}_{M S}$ metric to quickly and accurately quantify the relative binding strength from mass spectrometry data. $\mathrm{FA}_{M S}$ is expressed as a percentage and is determined from the fraction of the intensity of the [protein + fragment] peaks relative to total protein peaks, Equation 1, where $\mathrm{I}_{[\mathrm{P}: \mathrm{F}]}$ and $\mathrm{I}_{[P]}$ are the mass spectrometric peak intensities of the [protein + fragment] complexes and free/acetate bound protein, respectively, in the ESI mass spectrum. FA ${ }_{M S}$ values for CA II and fragment, 
when equimolar amounts of protein and fragment $(7.5 \mu \mathrm{M}$ each) are analysed, are in Table 1 (columns 3 and 4).

$$
\mathrm{FA}_{M S}=\frac{\mathrm{I}_{[\mathrm{P}: \mathrm{F}]}}{\mathrm{I}_{[\mathrm{P}: \mathrm{F}]}+\mathrm{I}_{[P]}} \times 100 \% \quad \text { Equation } 1 .
$$

Next $K_{D}$ values were determined for eight of the hit fragments (insufficient sample of 14' available at time of experiment). Experiments were performed with CA II (14.5 $\mu \mathrm{M})$ titrated against at least five different fragment concentrations ([F] range $0.5 \mu \mathrm{M}-120 \mu \mathrm{M})$ until either full complexation was observed (i.e. $\mathrm{I}_{[P]}=0$ ) or the fragment concentration reached $120 \mu \mathrm{M}$. The $\mathrm{FA}_{M S}$ was calculated for each fragment concentration and values plotted against fragment concentration $[\mathrm{F}]$. The $\mathrm{K}_{\mathrm{D}}$ was calculated upon curve fitting this plot based on Hill slope analysis, Figure $5 .{ }^{46} \mathrm{~K} \mathrm{DS}$ determined by nanoESI-MS ranged from 2.3-50.7 $\mu \mathrm{M}$, (Table 1, columns 5 and 6). Representative mass spectra showing the +10 charge state acquired for the CA II $+\mathbf{2 4}$ titration $\left(\mathrm{K}_{\mathrm{D}}=16.7 \mu \mathrm{M}\right)$ are presented in Figure 6. All observed charge states $(+9$, +10 and +11 ) were utilised for both $\mathrm{FA}_{M S}$ and $\mathrm{K}_{\mathrm{D}}$ calculations (Table 1, columns 3 and 5). Additionally for comparison, $\mathrm{FA}_{M S}$ and $\mathrm{K}_{\mathrm{D}}$ calculations were performed using only the peak intensities for the +10 charge state, (Table 1 , columns 4 and 6$)$. The single charge state $(+10$ only) calculated values are in excellent agreement with calculated values using all charge states $(+9,+10$ and +11$)$, indicating that the single charge state calculation of $\mathrm{FA}_{M S}$ and $\mathrm{K}_{\mathrm{D}}$ will be sufficient for future fragment screening campaigns using nanoESI-MS. The method employed for all the nanoESI-MS analyses has been optimised to ensure gentle conditions and avoid insource dissociation, so that the observed peak ratios in the mass spectra reflect the solution concentrations. The ionisation efficiency of the free protein and the protein:fragment complex is assumed the same. It is also noted that the equimolar $\mathrm{FA}_{M S}$ values provide a useful rank order of affinity compared to $\mathrm{K}_{\mathrm{D}}$ calculations determined from more laborious and higher sample 
consuming titration experiments, the overall trend is consistent, while for the weaker bound fragments in particular $\left(\mathbf{1 7}, \mathbf{2 2}\right.$ and $\mathbf{2 7 / 2 7 ^ { \prime } )}$ the correlation is excellent.



Figure 5. Saturation curves of the nanoESI-MS titration of eight hit fragments with CA II (14.5 $\mu \mathrm{M}) . \mathrm{FA}_{M S}$, as calculated at each fragment concentration using all observed charge states $(+9$, +10 and +11$)$, is plotted against total fragment concentration $[\mathrm{F}]$ with curve fitting based on Hill slope analysis used to determine $\mathrm{K}_{\mathrm{D}}{ }^{46}$ 


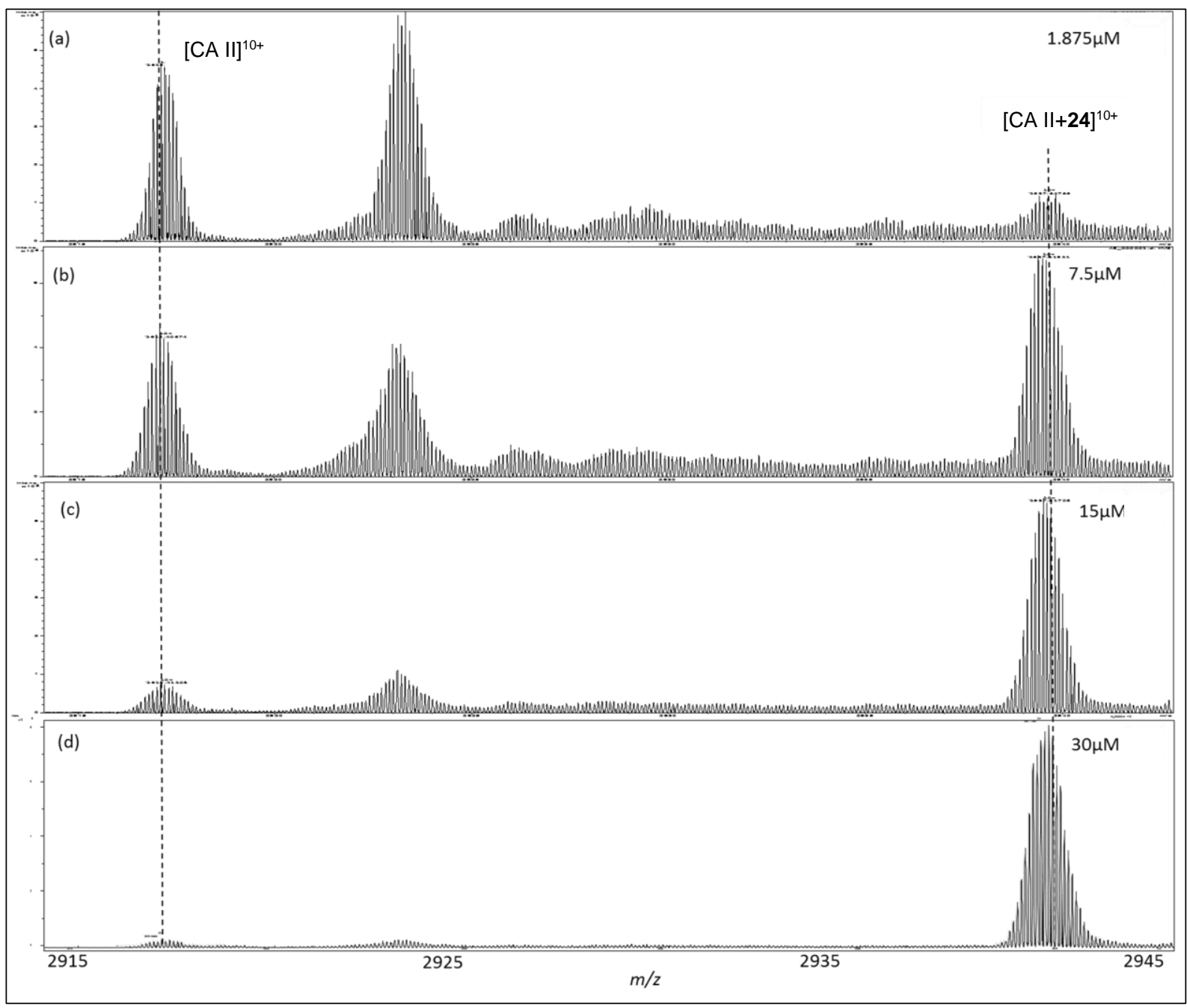

Figure 6. Representative positive ion mode nanoESI mass spectra (+10 charge state) of 14.4 $\mu \mathrm{M}$ hCA II (pH $7.410 \mathrm{mM} \mathrm{NH}_{4} \mathrm{OAc}$ ) titrated with fragment $\mathbf{2 4}$ to determine fragment $\mathrm{K}_{\mathrm{D}}$ by nanoESI-MS: (a) $1.875 \mu \mathrm{M}$ of $\mathbf{2 4}$; (b) $7.5 \mu \mathrm{M}$ of 24; (c) $15 \mu \mathrm{M}$ of 24; and (d) $30 \mu \mathrm{M}$ of 24 .

SPR was used as a secondary orthogonal fragment screening method for fragments 10, 11, 1329. Minimally biotinylated CA II was immobilised on a SPR sensor chip surface via biotinstreptavidin interactions, and the SAR fragment library analysed in dose-response experiments, performed at $25^{\circ} \mathrm{C}$ across a 5-point fragment concentration series range, to determine the $\mathrm{K}_{\mathrm{D}}$ of the fragments, Table 1 (column 2). SPR analysis identified the same nine fragments $(\mathbf{1 0}, \mathbf{1 1}$, 13, 14 (revised to $14^{\prime}$ following X-ray crystallography), 17, 22, 24, 25 and 27 (revised to a

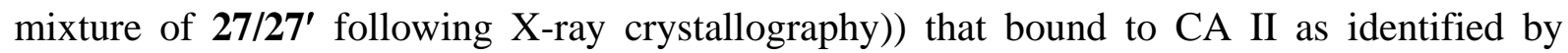


nanoESI-MS, with $\mathrm{K}_{\mathrm{DS}}$ that ranged from 3.4-65.5 $\mu \mathrm{M}$ (excluding 22), Table 1 (column 2). The $\mathrm{K}_{\mathrm{D}}$ values calculated by the nanoESI-MS experiments are in good agreement $\left(\mathrm{K}_{\mathrm{D}}\right.$ range 2.3$50.7 \mu \mathrm{M})$ with the values measured in solution by SPR. The only significant discrepancy appears in the $\mathrm{K}_{\mathrm{D}}$ values of fragment 22 (nanoESI-MS $\mathrm{K}_{\mathrm{D}}=35.8 \mu \mathrm{M}, \mathrm{SPR} \mathrm{K}_{\mathrm{D}}=355 \mu \mathrm{M}$ ) however the $\mathrm{K}_{\mathrm{D}}$ for $\mathbf{2 2}$ could not be reliably determined by SPR due to solubility issues of this compound in the SPR buffer and this issue is likely responsible for the discrepancy observed. Non-binding fragments $15,16,18-21,26,28$ and 29 were also fully consistent using the orthogonal methods, these fragments exhibited no detectable binding to CA II by either SPR or nanoESI-MS. Fragment $\mathbf{2 3}$ was only the only fragment discrepancy between nanoESI-MS and SPR. It was not detected by nanoESI-MS however was detected by SPR. Notably 23 had the weakest binding of the SPR hits $\left(K_{D}=1000 \mu \mathrm{M}\right)$, much weaker than all other hit fragments. The rank order of $K_{D S}$ by the two methods also followed a similar trend: nanoESI-MS $K_{D}$ values, low to high: $\mathbf{2 5}, \mathbf{1 0}, \mathbf{1 1}, \mathbf{1 7}, \mathbf{2 4}, \mathbf{1 3}, \mathbf{2 2}, \mathbf{2 7 / 2 7}$; SPR $K_{D}$ values, low to high: 25, 10, 11, 24, 17, 14', 13, 27/27', 22, 23. Binding sensorgrams for fragments interacting with the immobilised CA II are provided in Supporting Information. The findings that nanoESI-MS and SPR provide agreement of both the magnitude and trend of $K_{D}$ values suggests that the straightforward metric $\mathrm{FA}_{M S}$, with equimolar protein and fragment concentrations, offers the opportunity for rapid, semi-quantitative assessment of fragment binding strengths. If nanoESIMS is selected as a primary screen we propose that MS has potential to accelerate and inform the initial steps of FBDD. 
Table 1. Screening results for 10-29 using native state mass spectrometry, SPR and protein Xray crystallography.

\begin{tabular}{|c|c|c|c|c|c|c|}
\hline $\begin{array}{c}\text { Compound } \\
\text { No. }\end{array}$ & $\begin{array}{c}\text { SPR } \\
\mathbf{K}_{\mathbf{D}}(\mu \mathrm{M})\end{array}$ & $\begin{array}{c}\text { ESI-MS } \\
\text { FA }_{M S}(\%)^{c}\end{array}$ & $\begin{array}{c}\text { ESI-MS } \\
\text { FA }_{M S}(\%)^{d}\end{array}$ & $\begin{array}{c}\text { ESI-MS } \\
\mathbf{K}_{\mathbf{D}}(\mu \mathrm{M})^{c}\end{array}$ & $\begin{array}{c}\text { ESI-MS } \\
\mathbf{K}_{\mathbf{D}}(\mu \mathbf{M})^{d}\end{array}$ & $\begin{array}{l}\text { Protein } \\
\text { XRC }^{e}\end{array}$ \\
\hline 10 & 3.5 & 87.7 & 79.8 & 2.6 & 3.0 & $\mathrm{Y}$ \\
\hline 11 & 6.1 & 88.1 & 90.2 & 3.6 & 3.5 & $\mathrm{Y}$ \\
\hline 13 & 32.9 & 91.5 & 93.7 & 17.4 & 18.4 & $\mathrm{Y}$ \\
\hline $14^{\prime a}$ & 28.6 & 51.1 & 53.1 & n.d. ${ }^{f}$ & n.d. & $\mathrm{Y}$ \\
\hline 15 & $\mathrm{NSB}^{b}$ & NSB & NSB & n.d. & n.d. & n.d. \\
\hline 16 & NSB & NSB & NSB & n.d. & n.d. & n.d. \\
\hline 17 & 26.2 & 63.9 & 67.3 & 13.9 & 16.0 & $Y$ \\
\hline 18 & NSB & NSB & NSB & n.d. & n.d. & n.d. \\
\hline 19 & NSB & NSB & NSB & n.d. & n.d. & n.d. \\
\hline 20 & NSB & NSB & NSB & n.d. & n.d. & n.d. \\
\hline 21 & NSB & NSB & NSB & n.d. & n.d. & n.d. \\
\hline 22 & $355^{g}$ & 46.3 & 41.5 & 35.8 & 36.2 & $\mathrm{~N}$ \\
\hline 23 & 1000 & NSB & NSB & n.d. & n.d. & $\mathrm{N}$ \\
\hline 24 & 7.7 & 84.4 & 85.5 & 16.7 & 19.0 & $Y$ \\
\hline 25 & 3.4 & 68.7 & 74.5 & 2.3 & 2.7 & $\mathrm{Y}$ \\
\hline 26 & NSB & NSB & NSB & n.d. & n.d. & n.d. \\
\hline $27^{h}$ & 65.5 & 14.6 & 23.1 & 50.7 & 43.6 & $\mathrm{Y}^{h}$ \\
\hline 28 & NSB & NSB & NSB & n.d. & n.d. & n.d. \\
\hline 29 & $\mathrm{NSB}^{a}$ & NSB & NSB & n.d. & n.d. & n.d. \\
\hline
\end{tabular}


${ }^{a}$ The structure of $\mathbf{1 4}$ was revised to $\mathbf{1 4}^{\prime}$ following X-ray crystallography. ${ }^{b} \mathrm{NSB}=$ No significant binding $\left(\mathrm{K}_{\mathrm{D}}>2000\right.$ $\mu \mathrm{M}) ;{ }^{c}$ using all observed charge states $(+9,+10$ and +11$) ;{ }^{d}$ using only +10 charge state; ${ }^{e} \mathrm{XRC}-\mathrm{X}-\mathrm{ray}$ crystallography. ${ }^{f}$ n.d. - not determined; ${ }^{g} \mathrm{~K}_{\mathrm{D}}$ (SPR) could not be reliably determined due to solubility issues of this compound in the SPR buffer. ${ }^{h}$ the electron density of the fragment observed did not correlate with the structure of $\mathbf{2 7}$ but instead to an impurity in the sample, later identified as $\mathbf{2 7}$ '.

\section{Protein X-ray Crystallography}

The hit fragments identified from the orthogonal fragment screening $(\mathbf{1 0}, \mathbf{1 1}, \mathbf{1 3}, \mathbf{1 4}, \mathbf{1 7}, \mathbf{2 2}, \mathbf{2 3}$, 24, 25 and 27) were subjected to X-ray crystallography following soaking with CA II crystals as described earlier. ${ }^{29}$ Eight of the ten soaked fragments led to CA II:fragment structures observed by X-ray crystallography, all fragments bound via interaction of the acidic imide nitrogen with the hCA II active site zinc (1.9-2.0 $\AA$ ) and with the Thr199 side chain hydroxyl (3.1-3.2 ̊) (Figure 7, Table 2 and Supporting Information). The eight observed fragments include the original oxazolidinedione chemotypes $\mathbf{1 0}$ and $\mathbf{1 1}$, the thiazolidinedione chemotypes 13 and 17, and rhodanine chemotypes 24 and 25 . The structure of thiazolidinedione 14 was revised to 2-thioxo-1,3-oxazolidin-4-one $\mathbf{1 4}^{\prime}$ following X-ray crystallography. The electron density of this fragment clearly showed an exocyclic sulfur (as thiocarbonyl), rather than sulfur within the ring, Figure 7D. Both $\mathbf{1 4}$ and $\mathbf{1 4}$ ' are conceivable products from the synthesis, however they have an identical chemical formula and are also difficult to distinguish using NMR spectroscopy. The thiohydantoin chemotype 27 provided a structure following soaking, however the electron density showed that there was an additional atom attached to C-5 of the ring (Figures 7 and 8) and could not be correlated with the proposed structure of 27 . The electron density observed for $\mathbf{2 7}^{\prime}$ is consistent with either an $\mathrm{OH}$ or $\mathrm{NH}_{2}$ substituent at $\mathrm{C}-5$, Figure 8 . We re-examined a sample of 27 by LCMS and HRMS and this showed that the sample was a mixture of $27(\sim 95 \%)$ and the hydrated compound 27' ( 5\%) (Figure 8). Co-formation of C-5 benzylidine thiohydantoins with hydrated C-5 hydroxy/C-5 benzyl thiohydantoins has 
been reported. ${ }^{47}$ As $\mathbf{2 7}$ ' makes additional interactions over $\mathbf{2 7}$, it is plausible to imagine $\mathbf{2 7}$ easily outcompeting $\mathbf{2 7}$ for the CA II binding site. Structures for $\mathbf{1 0}$ and 11, Figure 7A and 7B, were described earlier in the introduction. For thiazolidinediones 13 and $\mathbf{1 7}$ (5-10-fold weaker binders than oxazolidinediones $\mathbf{1 0}$ and $\mathbf{1 1}$ ), unlike the hydrogen bond formed with the ring - $\mathrm{O}-$ of oxazolidinediones 10 and 11 and the Thr199 backbone nitrogen, there is no corresponding hydrogen bond formed between the ring -S- of $\mathbf{1 3}$ and $\mathbf{1 7}$ and the Thr199 backbone nitrogen, Figure 7C and 7E. For 14', Figure 7D, the thiocarbonyl is too far away from Thr199 to make any reasonable hydrogen bonds, however the ring $-\mathrm{O}-$ is $3.1 \AA$ from the backbone nitrogen of Thr199, similar to the distance seen in compounds $\mathbf{1 0}$ and $\mathbf{1 1}(\sim 3.0 \AA$ A). Rhodanine $\mathbf{2 5}$ (nanoESIMS K $K_{D}=2.7 \mu \mathrm{M}$, SPR $\left.K_{D}=3.4 \mu \mathrm{M}\right)$ and rhodanine $24\left(\right.$ nanoESI-MS $K_{D}=19 \mu \mathrm{M}$, SPR $K_{D}=$ $7.7 \mu \mathrm{M})$ are relatively strong binders, but neither the ring $-\mathrm{S}-$ nor the thiocarbonyl of $\mathbf{2 4}$ or $\mathbf{2 5}$ make any H-bond interactions with CA II, Figure 7F and 7G.

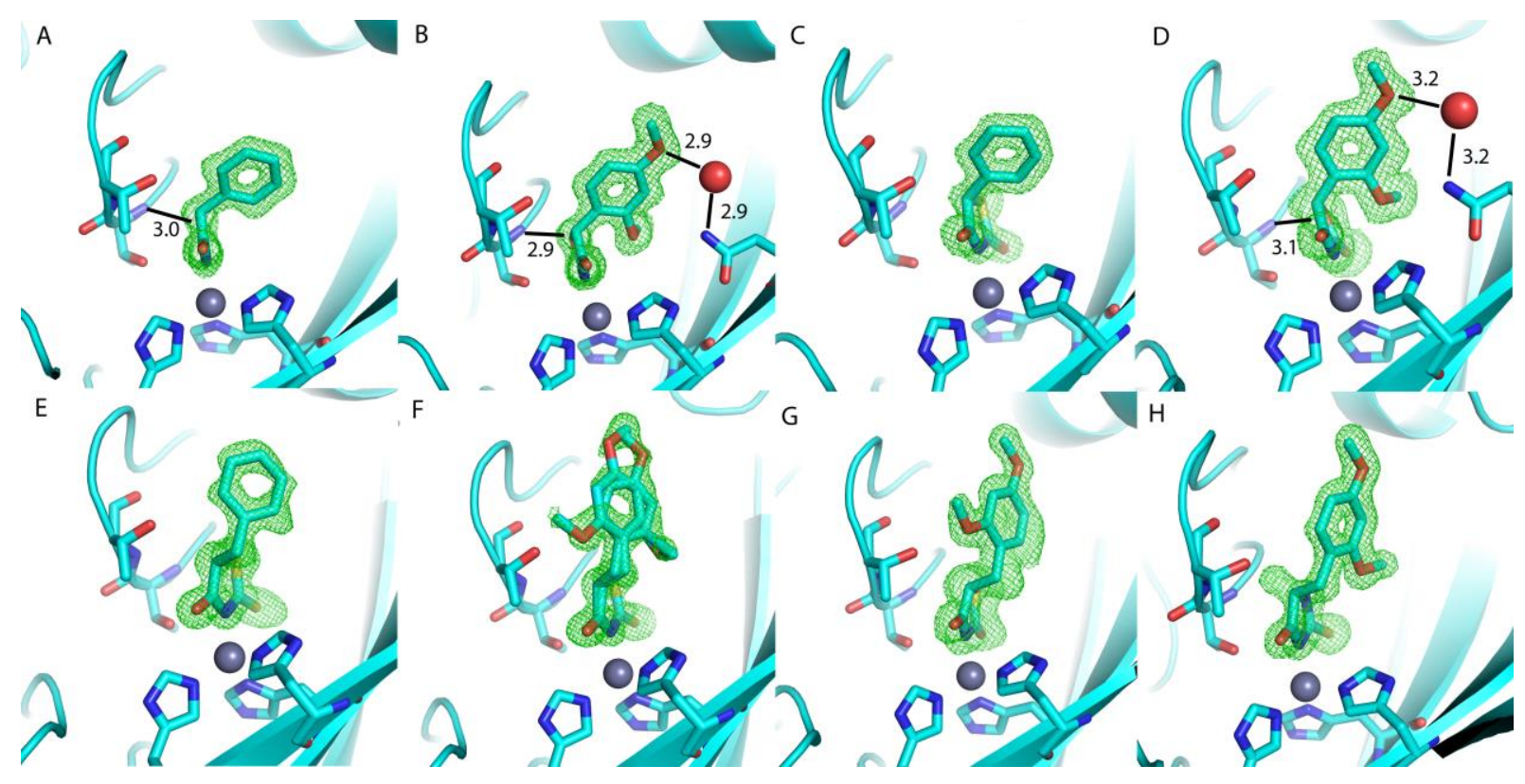

Figure 7. Difference density maps of fragments in the CA II binding site. (A) 10, oxazolidinedione chemotype. (B) 11, oxazolidinedione chemotype. (C) 13, thiazolidinedione 
chemotype. (D) 14' 2-thioxo-1,3-oxazolidin-4-one chemotype. (E) 17, thiazolidinedione chemotype. (F) $\mathbf{2 4}$, rhodanine chemotype. (G) 25, rhodanine chemotype. $(\mathrm{H}) \mathbf{2 7}$, thiohydantoin chemotype. Difference density (mFo-DFc) for all maps is shown at a $3 \sigma$ contour level where the fragments were omitted from the model. The active site zinc atom is represented as a grey sphere. Thr199, Thr200 and the three catalytic His residues (His94, His96 and His119) are shown. There is a water molecule (red sphere) within hydrogen bonding distance of a methoxy substituent for compounds 11 and 14' (B and D). Additionally, for compounds 10, 11 and 14' the ring oxygen is within hydrogen bonding distance of the backbone nitrogen of Thr199 and this distance is shown (A, B and D). Also note $\mathbf{2 4}(\mathrm{F})$ is modelled in two orientations for the dimethoxyphenyl group whereas the other compounds with this group had one preferred orientation $\left(11,14^{\prime}, 25\right.$ and $\left.27^{\prime}\right)$.

Table 2. Interactions of compounds with CA II identified by protein X-ray crystallography.

\begin{tabular}{|c|c|c|c|c|c|c|}
\hline \multirow{2}{*}{$\begin{array}{c}\text { Compoun } \\
\text { d }\end{array}$} & \multirow[b]{2}{*}{ PDB ID } & \multicolumn{5}{|c|}{ Protein-fragment interaction $(\AA)$} \\
\hline & & $\mathrm{Zn}-\mathrm{NH}$ & $\begin{array}{c}\text { T199OH- } \\
\text { NH }\end{array}$ & $\begin{array}{c}\text { T199N- } \\
\text { O1 }\end{array}$ & $\begin{array}{c}\text { T200NH- } \\
\mathrm{OH}\end{array}$ & $\begin{array}{c}\text { T200OH- } \\
\mathrm{OH}\end{array}$ \\
\hline 10 & $\begin{array}{c}\text { 5TXY and } \\
5 \mathrm{TY} 8\end{array}$ & 1.9 & 3.2 & 3.0 & - & - \\
\hline 11 & $5 \mathrm{TY9}$ & 2.0 & 3.1 & 2.9 & - & - \\
\hline 13 & 5TYA & 2.0 & 3.1 & - & - & - \\
\hline $14^{\prime}$ & 5U0D & 1.9 & 3.3 & 3.1 & - & - \\
\hline 17 & 5U0G & 2.0 & 3.1 & - & - & - \\
\hline 24 & $5 \mathrm{U} 0 \mathrm{E}$ & 2.0 & 3.2 & - & - & - \\
\hline 25 & 5U0F & 2.0 & 3.2 & - & - & - \\
\hline
\end{tabular}




\begin{tabular}{|l|l|l|l|l|l|l|}
\hline $\mathbf{2 7}^{\prime}$ & 5VGY & 1.9 & 3.1 & - & 2.9 & 2.6 \\
\hline
\end{tabular}

A.<smiles>COc1ccc(CC2NC(=S)NC2=O)c(OC)c1</smiles>

27<smiles>COc1ccc(C[C@@H]2NC(=S)NC2=O)c(OC)c1</smiles>

$27^{\prime}$

B.

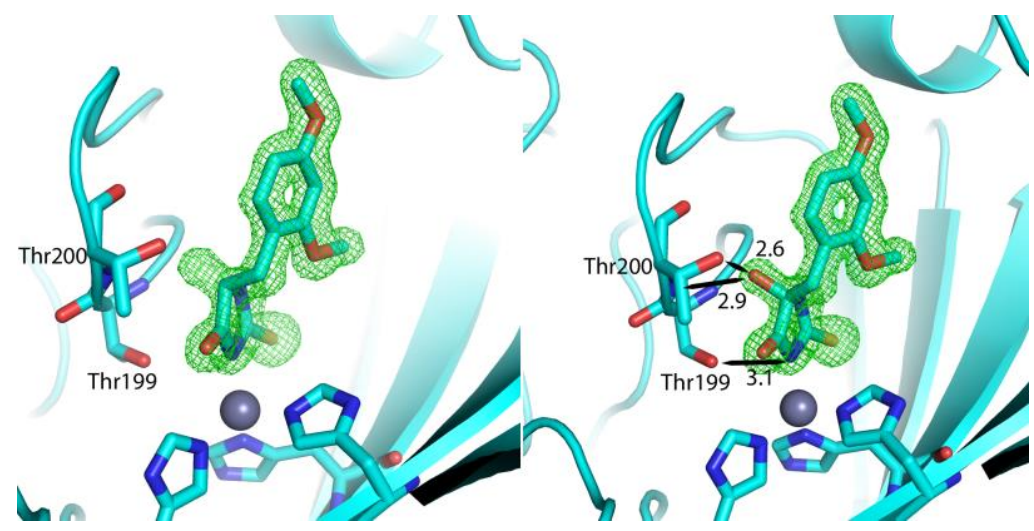

Figure 8. The electron density observed for compound $\mathbf{2 7}$ with CA II is consistent with an $\mathrm{OH}$ substituent at C-5 (27'). Compound $\mathbf{2 7 ^ { \prime }}$ was subsequently identified as a $\sim 5 \%$ impurity in $\mathbf{2 7}$. This oxygen makes two potential hydrogen bonds with the Thr200 residue: one at $2.6 \AA$ to the sidechain hydroxyl and another at $2.9 \AA$ to the backbone nitrogen (shown in figure).

The two fragments that failed to provide electron density in the CA II protein X-ray crystal structures were fragments $\mathbf{2 2}$ and $\mathbf{2 3}$. As discussed above, fragment $\mathbf{2 3}$ was the weakest binding of the ten SPR hits $\left(\mathrm{K}_{\mathrm{D}}=1000 \mu \mathrm{M}\right)$ and was not detected by nanoESI-MS. Notably, fragment 22 provided the only significant discrepancy in the $\mathrm{K}_{\mathrm{D}}$ values determined by nanoESI-MS and 
SPR, however this fragment had solubility issues at the higher concentration required for SPR analysis and this may have affected its ability to be seen in the crystallographic studies as well.

\section{Structure-Activity Relationships}

The strong binding properties of oxazolidinediones 10 and 11 shown previously were confirmed in the present study $\left(\mathrm{SPR} \mathrm{K}_{\mathrm{D}}=3.5 \mu \mathrm{M}\right.$, nanoESI-MS $\mathrm{K}_{\mathrm{D}}=2.6 \mu \mathrm{M}$ and SPR $\mathrm{K}_{\mathrm{D}}=$ $6.1 \mu \mathrm{M}, \mathrm{MS} \mathrm{K}_{\mathrm{D}}=3.6 \mu \mathrm{M}$, respectively). Fragments $\mathbf{1 0}$ and $\mathbf{1 1}$ have similar affinity, indicating that the two methoxy groups of the dimethoxyphenyl moiety of $\mathbf{1 1}$ do not significantly impact on binding even though they introduce steric bulk on to the phenyl ring ( $c f .10)$ and are electron withdrawing. Replacement of the ring $-\mathrm{O}-$ of oxazolidinediones $\mathbf{1 0}$ and $\mathbf{1 1}$ with $-\mathrm{S}-$ gave the corresponding thiazolidinedione $\mathbf{1 3}$, this change resulted in a $\sim 10$-fold reduction in CA II affinity. The larger size of sulfur relative to oxygen alters the orientation of the ring in the active site, the ring -S- is positioned $3.7 \AA$ from the backbone nitrogen of Thr199, whereas in compounds $\mathbf{1 0}$ and $\mathbf{1 1}$ the corresponding distance from the ring-O- is 2.9 to $3.0 \AA$, Table 2 . Replacement of the exocyclic carbonyl of oxazolidinedione 11 with a thiocarbonyl gave the 2thioxo-1,3-oxazolidin-4-one $\mathbf{1 4}^{\prime}$, this change resulted in a $\sim 10$-fold reduction on CA II affinity; however the ring oxygen of $\mathbf{1 4}^{\prime}$ is $3.1 \AA$ from the backbone nitrogen of Thr199, similar to the corresponding interaction of compounds 10 and $\mathbf{1 1}$. The sulfur atom of the thiocarbonyl of 14' is too far away from Thr199 to make any reasonable hydrogen bonds. The dimethoxybenzyl group of thiazolidinedione $\mathbf{1 7}$ was tolerated with one of the methoxy groups making a potential hydrogen bond with the sidechain hydroxyl of Thr200 (3.0 А), however the more rigid dimethoxybenzylidine group in thiazolidinedione $\mathbf{1 6}$ resulted in loss of binding to CA II. Similarly the dimethoxybenzylidine thiohydantoin $\mathbf{2 6}$ was a nonbinder, while dimethoxybenzyl thiohydantoin $\mathbf{2 7}$ (an impurity in 27) was observed (Figure 8) but as a weaker binder (SPR of mixture $K_{D}=65.5 \mu \mathrm{M}$, nanoESI-MS of mixture $K_{D}=43.6 \mu \mathrm{M}$ ) than 10 and $\mathbf{1 1}$. The introduction 
of the $-\mathrm{NH}-$ in the ring of hydantoins $(\mathbf{1 5}, \mathbf{1 8}$ - 21) abolished binding completely, irrespective of most of the 5-substituents, the exception being $27^{\prime}$ with the added hydroxyl. This SAR suggests that a hydrogen bond acceptor in the ring 1-position (-O-) provides the additional binding affinity observed, this is consistent with the crystal structures for $\mathbf{1 0}$ and $\mathbf{1 1}$. Rhodanines 24 (benzyl) and 25 (dimethoxybenzyl) were strong binders, although the electron density shows that the $-\mathrm{S}-$ in the ring is too far away from Thr199 to make a hydrogen bond ( $3.7 \AA$ ) compared to the $-\mathrm{O}-$ in the ring of lead oxazolidinediones, $\mathbf{1 0}$ and $\mathbf{1 1}$. Rhodanines $\mathbf{2 2}$ (5-benzylidine substituent) and $\mathbf{2 3}$ (5-dimethoxybenzylidine substituent) failed to give a crystal structure while the reduced binding observed by nanoESI-MS and SPR, suggests that the flexibility of the 5substituent may be important as connection through the $\mathrm{sp}^{2}$ hybridised carbon of the benzylidine substituents hinders hCA II binding. Rhodanine is identified as a 'PAIN' as this chemotype leads to pan-assay interference. ${ }^{48}$ Our findings indicate that CA II is a possible off-target enzyme of 5-subtituted rhodanine compounds, but that any binding is likely dependent also on the nature of the 5-substituent. To the best of our knowledge, CA II as an off-target of rhodanines was not previously known, given that CA II is a ubiquitous enzyme this finding may provide further caution on the decision to advance rhodanine compounds in medicinal chemistry campaigns. Benzylidine substitution at C5 of the thiazolidinedione $\mathbf{1 6}$ and thiohydantoin $\mathbf{2 6}$ was also poorly tolerated, while both a 5-phenyl or 5-benzyl group on these heterocycles was tolerated, this is consistent with the SAR observed for rhodanines. Finally, trimethadione $\mathbf{2 8}$ and dimethadione $\mathbf{2 9}$ have no binding to hCA II.

Given that the 3-unsubstituted-2,4-oxazolidinedione fragment is not known as a ZBG in the PDB, we next searched the PDB for protein:ligand crystal structures comprising the other hit fragments (as 3-unsubstituted heterocycles) to see if they are known as metal binding groups. The 2-thioxo-1,3-oxazolidin-4-one fragment of $\mathbf{1 4}^{\prime}$ is not in the PDB. One protein:ligand crystal 
structure where the ligand comprises a 3 -unsubstituted thiohydantoin fragment as in $\mathbf{2 7} \mathbf{\prime}^{\prime}$ is known, PDB ID 1HLF. ${ }^{49}$ The ligand in structure 1HLF is glucopyranosylidene-spirothiohydantoin, while the protein is glycogen phosphorylase B, not a metalloprotein. Three protein:rhodanine structures, with a 3-unsubstituted rhodanine, as in $\mathbf{2 4}$ and $\mathbf{2 5}$, are known, all with the bacterial enzyme MurD ligase, also not a metalloprotein (PDB IDs 2WJP, 2Y68 and 2Y1O). ${ }^{50-52}$ There were more than 20 protein:ligand structures in the PDB for the 3unsubstituted 1,3-thiazolidine-2,4-dione fragment, many with antidiabetic drugs that comprise this fragment, and similarly to the 3-unsubstituted-2,4-oxazolidinedione (12) inhibit gamma peroxisome proliferator-activated receptor ( $\gamma$ PPAR). Rosiglitazone, an antidiabetic drug within this fragment class appears in eight $\gamma$ PPAR related structures including PDB ID 2PRG. ${ }^{53}$ Structures of the antidiabetic drugs pioglitazone and rosiglitazone in complex with monoamine oxidase B (PDB ID $4 \mathrm{AZ}^{54}$ and $4 \mathrm{~A}^{7} \mathrm{~A}^{54}$, respectively) and troglitazone in complex with cytochrome P450 2C8 (PDB ID 2VN0) are also known. Other thiazolidinedione structures are found bound to Pim-1 kinase (PDB ID 3VC4, ${ }^{55} 3 \mathrm{ZW} 3^{56}$ and PDB ID 4DTK ${ }^{57}$ ); estrogen related receptor alpha (PDB ID 3K6P); phosphoinositide 3-kinase gamma (PI3K $\gamma$ ) (PDB ID 2A4Z ${ }^{58}$ and 2A5U ${ }^{56}$ ); CDK2 (PDB ID 2UZO); ${ }^{59}$ MurD ligase (PDB ID 2Y66, 2Y67, 2 X50 - similar to rhodanine structures with this enzyme mentioned above $)^{50,60}$ and with fatty acid-binding protein 4 (FABP4) (PDB ID 2QM9 ) - none of which have the fragment bound to a metal ion. ${ }^{61}$

Interestingly, the hydantoin chemotype, although displaying no CA II binding in this study, is known as a ZBG. X-ray crystal structures of a 5-substituted hydantoin with the zinc metalloenzyme, tumour necrosis factor- $\alpha$ (TNF- $\alpha$ ) converting enzyme (TACE), have the acidic imide nitrogen of the hydantoin coordinated to the zinc of TACE (PDB IDs 3LOT and 3L0V ${ }^{62}$, 3LE9 and $3 \mathrm{LEA}^{63}$ ). Additionally, structures with a disintegrin and metalloproteinase with thrombospondin motifs-4 (ADAMTS-4) (PDB IDs 4WK7, 4WKE, 4WKI) also have the imide 
nitrogen of the hydantoin ring interacting directly with the catalytic zinc. ${ }^{64}$ Further structures with matrix metalloproteins (MMP) are reported (3UVC with MMP12, 4JPA with MMP13 $3^{65}$ ) showing a zinc interaction with the ligand. The zinc in these enzymes is coordinated to three protein histidine residues, the same coordination as found in hCA II.

Collectively the SAR generated in this study confirms the importance of the acidic cyclic imide $\mathrm{NH}$ group for the oxazolidinedione and other heterocycles to act as a ZBG. The SAR is however more informative, it demonstrates that the zinc interaction alone is not sufficient for good CA II binding but rather that a interdependent combination of the acidic imide, ring heteroatom (with $\mathrm{O}>\mathrm{S}>\mathrm{NH}$ ) and 2-carbonyl/thiocarbonyl group in parallel with the introduction of a flexible 5-substituent contribute to the strength and specificity of CA II binding. We have identified 3-unsubstituted 2,4-oxazolidinedione, 2-thioxo-1,3-oxazolidin-4-one, thiohydantoin and 1,3-thiazolidine-2,4-dione fragments as ZBGs which were not previously known in the PDB. All have potential for CA targeting strategies with new chemical entities. In contrast, the hydantoin chemotype is previously known as a ZBG yet displayed no CA II binding. Together with the SAR of this study, the findings in the PDB indicate that selective targeting of zinc metalloenzymes is possible through a combination of ligand structural features and is not limited solely to the ZBG.

\section{Chemical Synthesis}

The synthetic route to 2,4-oxazolidinediones 10 and 11, 2,4-thiazolidinediones 13 and 2-thioxo1,3-oxazolidin-4-one $\mathbf{1 4}^{\prime}$ is presented in Scheme 1. Palladium-catalysed Suzuki-Miyaura coupling reaction of the phenyl boronic acids $\mathbf{1 a - b}$ with ethyl glyoxylate generated the precursor mandelic acid ethyl esters $\mathbf{2 a - b}$ in good yield. ${ }^{66}$ Condensation of $\mathbf{2 a - b}$ with urea or thiourea in the presence of $\mathrm{NaOEt}(21 \mathrm{wt} \%$ in ethanol), followed by acidification with $\mathrm{HCl}$ 
$(1.0 \mathrm{~N})$, provided the target oxazolidinediones 10 and 11, 2,4-thiazolidinediones 13 and 2thioxo-1,3-oxazolidin-4-one $\mathbf{1 4}^{\prime}$, respectively. ${ }^{67}$

Scheme 1. Synthesis of oxazolidindione (10 and 11), thiazolidinedione (13) and 2-thioxo-1,3oxazolidin-4-one (14') fragments.

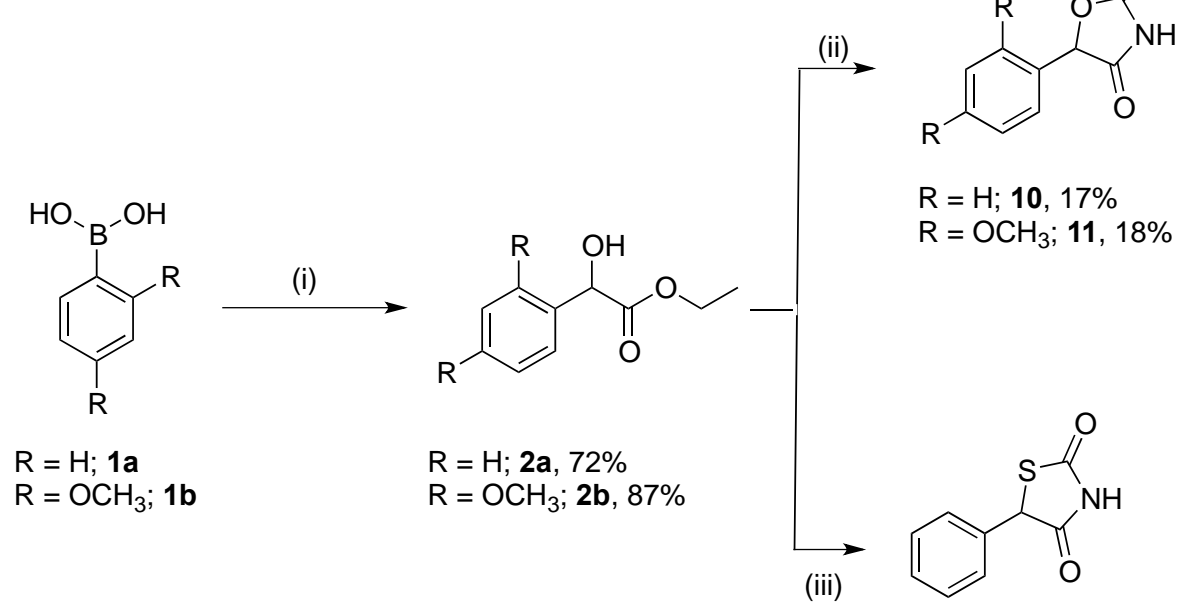

$13,4 \%$<smiles>COc1ccc(C2OC(=S)NC2=O)c(OC)c1</smiles>

$14 ', 3 \%$

Reagents and conditions: (i) ethyl glyoxylate, $\mathrm{Pd}_{2}(\mathrm{dba})_{3} \cdot \mathrm{CHCl}_{3}, \quad$ 2-(di-tertbutylphosphino)biphenyl, $\mathrm{Cs}_{2} \mathrm{CO}_{3}$, toluene $80{ }^{\circ} \mathrm{C}, 4-5 \mathrm{~h}$; (ii) urea, 21 wt. \% $\mathrm{NaOEt}$ in $\mathrm{EtOH}$, dry EtOH, $0{ }^{\circ} \mathrm{C}-\mathrm{rt}, 30 \mathrm{~min}$, then reflux $3.5 \mathrm{~h}$; (iii) thiourea, 21 wt. \% $\mathrm{NaOEt}$ in EtOH, dry EtOH, $0{ }^{\circ} \mathrm{C}-\mathrm{rt} 30 \mathrm{~min}$, then reflux $3.5 \mathrm{~h}$.

Benzylidine hydantoins 18 and 19 were synthesised by acid mediated coupling of hydantoin with benzaldehydes 3a-b followed by hydrolysis, Scheme 2. Reduction of the benzylidine double bond proceeded with Pd-catalysed hydrogenation to provide the related benzyl hydantoins 20 and 21 in good yield, Scheme 2. Thiohydantoin fragment $\mathbf{2 6}$ was prepared similarly to $\mathbf{1 9}$ from $\mathbf{3 b}$ and thiohydantoin instead of hydantoin, Scheme $2 .{ }^{68}$ Attempts to reduce the benzylidine double bond of $\mathbf{2 6}$ with $\mathrm{Pd} / \mathrm{C}$ or $\mathrm{Pd}(\mathrm{OH})_{2}$ catalysed hydrogenation, transfer hydrogenation or $2.0 \mathrm{M} \mathrm{LiBH}_{4}$ in THF resulted in no reaction. ${ }^{68}$ The reduction of 26 was 
however achieved with $\mathrm{Zn}-\mathrm{AcOH}$, affording benzyl thiohydantoin 27 in 65\% yield (Scheme 2). ${ }^{69}$

Scheme 2. Synthesis of hydantoin (18-21) and thiohydantoin (26 and 27) fragments.

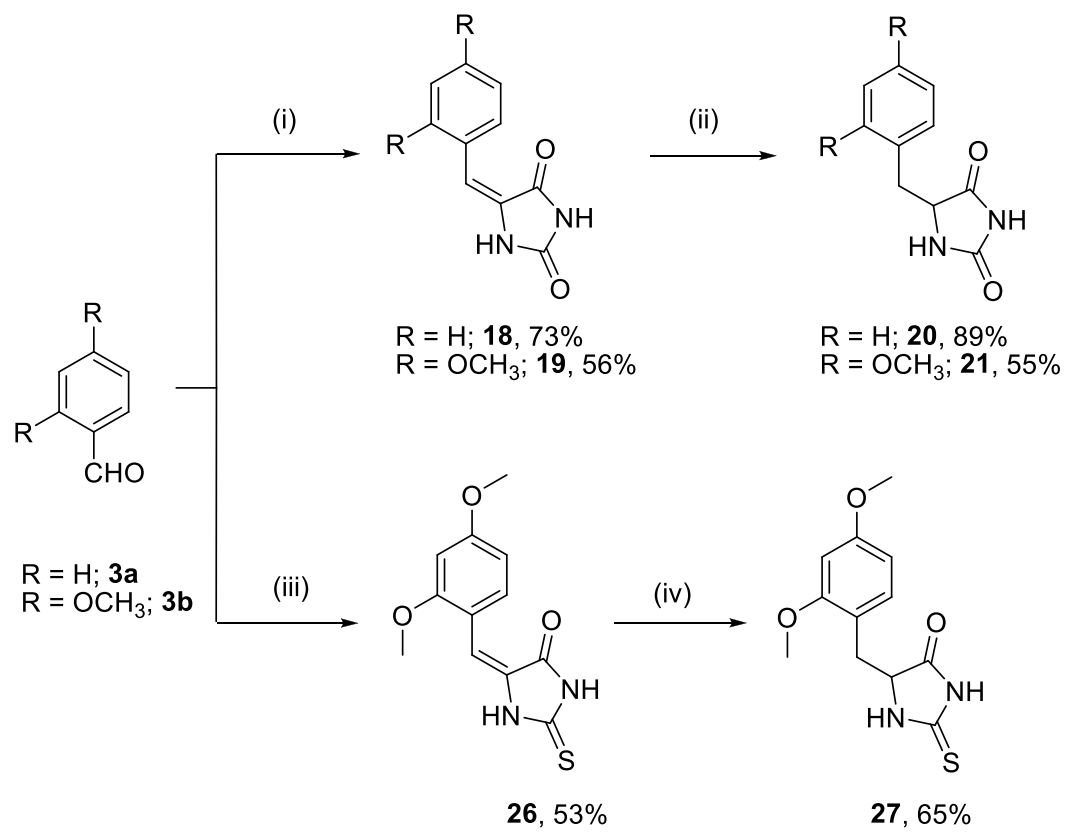

Reagents and conditions: (i) (a) hydantoin, anhyd. $\mathrm{NaOAc}, \mathrm{AcOH}, 170{ }^{\circ} \mathrm{C}, 3 \mathrm{~h}$; (b) $\mathrm{H}_{2} \mathrm{O}$, rt, overnight; (ii) $10 \% \mathrm{Pd} / \mathrm{C}, \mathrm{EtOH}, \mathrm{H}_{2}, \mathrm{rt}, 5$ h; (iii) (a) 2-thiohydantoin, anhyd. $\mathrm{NaOAc}, \mathrm{AcOH}$, $170{ }^{\circ} \mathrm{C}, 3 \mathrm{~h}$; (b) $\mathrm{H}_{2} \mathrm{O}$, rt, overnight; (iv) $\mathrm{Zn}, \mathrm{AcOH}$, reflux, overnight.

Benzaldehydes $\mathbf{3 a}$ and $\mathbf{3 b}$ were also the core reagent for the synthesis of thiazolidinediones 16$\mathbf{1 7}$ and rhodanines 22-25. Knoevenagel type condensation of $\mathbf{3 a}$ and $\mathbf{3 b}$ with rhodanine afforded benzylidine rhodanines $\mathbf{2 2}$ and $\mathbf{2 3}$, respectively, while reaction of $\mathbf{3 b}$ and 2,4-thiazolidinedione afforded benzylidene thiazolidinedione 16, Scheme $3 .^{70}$ Regiospecific reduction of the benzylidene double bond of $\mathbf{2 2 , 2 3}$ and $\mathbf{1 6}$ with $2.0 \mathrm{M} \mathrm{LiBH}_{4}$ in THF provided the corresponding benzyl rhodanines $\mathbf{2 4}$ and 25 and benzyl thiazolidinedione 17, respectively (Scheme 3). ${ }^{71}$

Scheme 3: Synthesis of 2,4-thiazolidinedione (16-17) and rhodanine (22-25) fragments. 


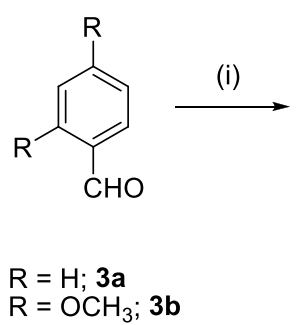



$\mathrm{R}=\mathrm{H}, \mathrm{X}=\mathrm{S} ; \mathbf{2 2}, 57 \%$

$\mathrm{R}=\mathrm{OCH}_{3}, \mathrm{X}=\mathrm{S} ; 23,82 \%$

$\mathrm{R}=\mathrm{OCH}_{3}, \mathrm{X}=\mathrm{O} ; \mathbf{1 6}, 70 \%$
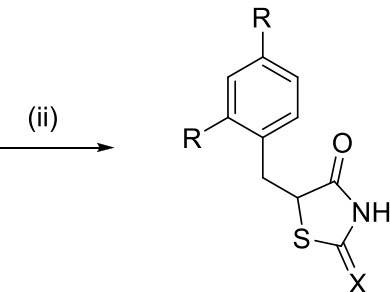

$\mathrm{R}=\mathrm{H}, \mathrm{X}=\mathrm{S} ; 24,21 \%$

$\mathrm{R}=\mathrm{OCH}_{3}, \mathrm{X}=\mathrm{S} ; 25,47 \%$

$\mathrm{R}=\mathrm{OCH}_{3}, \mathrm{X}=\mathrm{O} ; 17,39 \%$

Reagents and conditions: (i) rhodanine (for 22 and 23) or 2,4-thiazolidinedione (for 16), $\mathrm{NH}_{4} \mathrm{OAc}$, toluene, reflux, $3 \mathrm{~h}$; (ii) $2.0 \mathrm{M} \mathrm{LiBH}_{4}$ in THF, pyridine-THF, reflux, $5 \mathrm{~h}$; (iii) $2.0 \mathrm{M}$ $\mathrm{LiBH}_{4}$ in THF, pyridine-THF, reflux, $5 \mathrm{~h}$.

\section{Conclusion}

Here we have discovered a new zinc binding chemotype, 3-unsubstituted-2,4-oxazolidinedione, with affinity for CA II that is of a magnitude similar to fragment sized primary benzene sulfonamides. A cascade of biophysical screening methods was employed to evaluate binding to CA II, with native state nanoESI-MS evaluated for primary screening, with SPR and protein X-ray crystallography providing validation. We found that nanoESI-MS and SPR provided agreement of both the magnitude and trend of $\mathrm{K}_{\mathrm{D}}$ values. The straightforward metric of $\mathrm{FA}_{M S}$ appears to offer the opportunity for rapid, semi-quantitative assessment of fragment binding strength using nanoESI-MS as a primary screen in FBDD, while $\mathrm{K}_{\mathrm{D}}$ values determined using mass spectrometry provide quantitative data. Both mass spectrometry methods allow fragments to be ranked and prioritised based on affinity for the protein, with the many advantages outlined in our earlier study such as low protein concentration, low fragment concentration (reduces solubility problems), rapid analysis with no need for immobilisation of the protein. Our findings provide support for the relatively untapped opportunity to consider to apply native state mass spectrometry as a complementary fragment screening method to accelerate drug discovery. 
Furthermore, SAR by $\mathrm{MS}^{35}$ was employed and found to be highly suited to establish SAR around the initial hit fragment. Protein X-ray crystallography established that the 3unsubstituted-2,4-oxazolidinedione fragment bound to CA II via an interaction of the acidic ring nitrogen with the CA II active site zinc, as well as a hydrogen bond between the oxazolidinedione ring oxygen and the CA II protein backbone. A significant finding in relation to SAR was that hydantoins $(\mathbf{1 5}, \mathbf{1 8 - 2 1})$ had no affinity for CA II, even though the hydantoin heterocycle is known as a zinc binding chemotype with other proteins where the zinc is coordinated to three histidine residues, the same coordination as found in hCA II. ${ }^{63-65}$ Together these finding further demonstrate that the fragment-zinc interaction alone is not sufficient for strong CA II binding and that further H-bond interactions between the fragment and CA II are critical. This also indicates that CA II may be selectively targeted over other zinc metalloenzymes, consistent with the findings of CA II binding of the classical primary sulfonamides ${ }^{9}$ where the strong binding affinity and specificity of the primary sulfonamide functional group for CA II is attributed to two key hydrogen bonds with the CA II active site residues in addition to the zinc-sulfonamide interaction. ${ }^{34}$ To conclude, 3-unsubstituted-2,4oxazolidinedione, and other heterocycles presented herein, represent new and potentially useful starting points for development of novel and selective CA inhibitors. Additionally, native state mass spectrometry was successfully applied as a primary fragment screen, with successful extension to generate SAR using "fragment SAR by MS".

\section{Experimental}

General Chemistry. All reactions were carried out in dry solvents under anhydrous conditions, unless otherwise mentioned. All chemicals were purchased commercially and used without further purification. All reactions were monitored by TLC using silica plates with visualisation of product bands by UV fluorescence $(\lambda=254 \mathrm{~nm})$ and charring with Vanillin $(6 \mathrm{~g}$ vanillin in 
$100 \mathrm{~mL}$ of EtOH containing 1\% (v/v) concentrated sulfuric acid) stain. Silica gel flash chromatography was performed using silica gel $60 \AA$ (230-400 mesh). NMR $\left({ }^{1} \mathrm{H},{ }^{13} \mathrm{C}, \mathrm{COSY}\right.$, HSQC) spectra were recorded on the $500 \mathrm{MHz}$ spectrometer at $25^{\circ} \mathrm{C}$. Chemical shifts for ${ }^{1} \mathrm{H}$ and ${ }^{13} \mathrm{C}$ NMR obtained in DMSO- $d_{6}$ are reported in ppm relative to residual solvent proton $(\delta$ $=2.50 \mathrm{ppm})$ and carbon $(\delta=39.5 \mathrm{ppm})$ signals respectively. Multiplicity is indicated as follows: s (singlet), d (doublet), t (triplet), q (quartet), m (multiplet), dd (doublet of doublet), bs (broad signal). Coupling constants are reported in hertz (Hz). High- and low-resolution mass spectra were acquired using electrospray as the ionization technique in positive-ion and/or negativeion modes as stated. All MS analysis samples were prepared as solutions in methanol. Purity of compounds all compounds was $>95 \%$ as determined by HPLC instrument (Agilent 1100 series) with UV detection. The melting points are uncorrected. Proton and carbon atoms for NMR assignments are designated as shown in the Supporting Information.

General procedure 1: Suzuki-Miyaura coupling reaction to prepare mandelic esters.

To the appropriate boronic acid $\mathbf{1 a}$ or $\mathbf{1 b}$ (1.5 equiv) and $\mathrm{Cs}_{2} \mathrm{CO}_{3}$ (1 equiv) suspended in dry toulene at room temperature was added $\mathrm{Pd}_{2}(\mathrm{dba})_{3} \cdot \mathrm{CHCl}_{3}$ (0.0125 equiv), 2-di-tertbutylphoshphanylbiphenyl (0.05 equiv) and ethyl glyoxylate (1.0 equiv) under argon atmosphere. The reaction mixture was stirred at $80{ }^{\circ} \mathrm{C}$ for $4-5 \mathrm{~h}$. After completion of reaction (as evidenced by TLC), the reaction was quenched by addition of water (10-15 mL) and extracted with DCM $(3 \times 20 \mathrm{~mL})$. The combined organic extracts were washed with brine $(1 \times$ $15 \mathrm{~mL}$ ), dried over $\mathrm{MgSO}_{4}$ and concentrated in vacuo. The crude residue was purified by flash chromatography to provide mandelic esters $\mathbf{2 a}$ and $\mathbf{2 b}$, respectively.

General procedure 2: Synthesis of phenyl-2,4-oxazolidindione and phenyl-2,4thiazolidinedione fragments. 
A sodium ethoxide solution ( $21 \mathrm{wt} . \%$ in ethanol, 1.2 equiv) was cooled to $0{ }^{\circ} \mathrm{C}$ and urea (for phenyl-2,4-oxazolidindiones) or thiourea (for phenyl-2,4-thiazolidinediones) added (1 equiv) in one portion followed by dropwise addition of an ice-cold solution of mandelic ester (2a or $\mathbf{2 b}, 1$ equiv) in absolute $\mathrm{EtOH}(2-3 \mathrm{~mL})$ over $5 \mathrm{~min}$. The reaction mixture was allowed to warm to room temperature over 15-20 min and then refluxed for $3.5 \mathrm{~h}$. EtOH was evaporated under vacuum, the remaining residue was suspended in a mixture of water $(6 \mathrm{~mL})$ and $\mathrm{Et}_{2} \mathrm{O}(4 \mathrm{~mL})$, acidified with $1 \mathrm{~N} \mathrm{HCl}$ (to $\mathrm{pH} 2-4)$ and extracted with $\mathrm{Et}_{2} \mathrm{O}(2 \times 15 \mathrm{~mL})$. The combined organic extracts were washed with brine $(1 \times 10 \mathrm{~mL})$, dried over $\mathrm{MgSO}_{4}$ and concentrated in vacuo. The crude residue was purified by flash chromatography to provide fragments $\mathbf{1 0 - 1 1 , 1 3}$ and $14^{\prime}$.

General procedure 3: Synthesis of hydantoin and thiohydantoin fragments Hydantoin (1.1 equiv) was added to a solution of glacial acetic acid $(0.33 \mathrm{~mL} / \mathrm{mmol})$ and acetic anhydride $(0.044 \mathrm{~mL} / \mathrm{mmol})$ under argon atmosphere, followed by addition of anhydrous $\mathrm{NaOAc}$ ( 2 equiv), and benzaldehyde $\mathbf{3 a}$ or $\mathbf{3 b}$ ( 1 equiv). The resulting mixture was stirred at $170{ }^{\circ} \mathrm{C}$ under an argon atmosphere. After $3 \mathrm{~h}$, the reaction mixture was cooled to $110^{\circ} \mathrm{C}$, water was added and the mixture was stirred overnight at room temperature. The precipitate that formed was collected by filtration, washed with water $(4 \times 20 \mathrm{~mL})$ and purified by flash chromatography to provide the desired fragments 18 and 19. Fragment 26 was prepared similarly from 2-thiohydantoin (1.1 equiv) and benzaldehyde $\mathbf{3 b}$.

General procedure 4: Synthesis of 5-benzylimidazoline-2,4-dione (hydantoin) fragments. To a solution of $\mathbf{1 8}$ or $\mathbf{1 9}$ (1 equiv) in absolute EtOH was added $\mathrm{Pd} / \mathrm{C}$ ( $40 \%$ by weight of $\mathbf{1 8}$ or 19). The reaction mixture was stirred at room temperature overnight under an atmosphere of hydrogen. After completion of reaction (as evidenced by TLC), the reaction mixture was 
filtered through celite and the celite washed with $\mathrm{MeOH}(15-20 \mathrm{~mL})$. The solvent was evaporated in vacuo and the crude residue purified by flash chromatography to provide the fragments $\mathbf{2 0}$ and $\mathbf{2 1}$.

General procedure 5: Synthesis of 5-benzylidenethiazolidine-2,4-dione or 5-benzylidene-2sulfanylidene-1,3-thiazolidin-4-one (thiazolidinedione and rhodanine) fragments.

To an appropriate benzaldehyde $\mathbf{3 a}$ or $\mathbf{3 b}$ (1 equiv) in dry toulene $(10-15 \mathrm{~mL}$ ) at room temperature, was added rhodanine (1 equiv) or 2,4-thiazolidinedione (1 equiv) and anhydrous ammonium acetate (1.5 equiv) under argon atmosphere. The resultant reaction mixture stirred at $90-100{ }^{\circ} \mathrm{C}$ for $3 \mathrm{~h}$. After $3 \mathrm{~h}$, the precipitate of the desired product was filtered and washed with $\mathrm{Et}_{2} \mathrm{O}(2 \times 15 \mathrm{~mL})$. The crude solid was recrystallised in absolute $\mathrm{EtOH}$ to provide the desired compounds as described in the series of $\mathbf{1 6}$ and 22-23.

General procedure 6: Synthesis of 5-benzyl-2-sulfanylidene-1,3-thiazolidin-4-one or 5Benzylthiazolidine-2,4-dione (thiazolidinedione and rhodanine) fragments.

To a stirred solution of appropriate compound $\mathbf{1 6}$ or $\mathbf{2 2}$ or $\mathbf{2 3}$ (1 equiv) in dry pyridine $(0.81$ $\mathrm{mL} / \mathrm{mmol}$ ) and dry THF $(0.66 \mathrm{~mL} / \mathrm{mmol})$, was added $2.0 \mathrm{M} \mathrm{LiBH}_{4}$ in THF (2.2 equiv) at room temperature and under argon atmosphere (Effervescences were controlled by addition rate of $\mathrm{LiBH}_{4}$ solution). The resulting mixture was refluxed for 3-4 h. After completion of reaction (as evidenced by TLC), the reaction mixture was quenched by $1 \mathrm{~N} \mathrm{HCl}(1-2 \mathrm{~mL})$, extracted with EtOAc $(3 \times 15 \mathrm{~mL})$. The combined organic layers were washed with brine $(1 \times 10 \mathrm{~mL})$, dried over $\mathrm{MgSO}_{4}$ and concentrated in vacuo. The crude residue was purified by flash chromatography to provide the desired compounds as described in the series of $\mathbf{1 7}$ and $\mathbf{2 4 - 2 5}$.

Ethyl 2-hydroxy-2-phenylacetate (2a) ${ }^{66}$ 
Compound 2a was synthesized from ethyl glyoxylate $50 \%$ solution in toulene $(0.59 \mathrm{~mL}, 3.0$ mmol) and compound $\mathbf{1 a}(0.548 \mathrm{~g}, 4.50 \mathrm{mmol})$ according to general procedure 1 . The crude residue was purified by flash chromatography (Gradient: $8-10 \%$ EtOAc in $n$-hexane) to afford the title compound as a colorless oil $(0.394 \mathrm{~g}, 72.96 \%) . R_{f}=0.46$ (30\% EtOAc in $n$-hexane). ${ }^{1} \mathrm{H}$ NMR $\left(500 \mathrm{MHz}, \mathrm{CDCl}_{3}\right) \delta_{\mathrm{H}}=7.43-7.41\left(\mathrm{~m}, 2 \mathrm{H}, \mathrm{H}_{\mathrm{Ar}}\right), 7.38-7.35\left(\mathrm{~m}, 2 \mathrm{H}, \mathrm{H}_{\mathrm{Ar}}\right), 7.34-7.31$ $\left(\mathrm{m}, 1 \mathrm{H}, \mathrm{H}_{\mathrm{Ar}}\right), 5.16(\mathrm{~d}, J=5.25 \mathrm{~Hz}, 1 \mathrm{H}, \mathrm{OH}-\mathrm{C} \underline{\mathrm{H}}), 4.30-4.24\left(\mathrm{~m}, 1 \mathrm{H}, \mathrm{C} \underline{\mathrm{HH}}-\mathrm{CH}_{3}\right), 4.21-4.14(\mathrm{~m}$, $\left.1 \mathrm{H}, \mathrm{CH} \underline{\mathrm{H}}-\mathrm{CH}_{3}\right), 3.47$ (d, $\left.J=5.7 \mathrm{~Hz}, 1 \mathrm{H}, \mathrm{CH}-\mathrm{O} \underline{\mathrm{H}}\right), 1.23\left(\mathrm{t}, J=7.15 \mathrm{~Hz}, 3 \mathrm{H}, \mathrm{CH}_{2}-\mathrm{C}_{3}\right)$, general assignments were confirmed by ${ }^{1} \mathrm{H}-{ }^{1} \mathrm{H}$ gCOSY $.{ }^{13} \mathrm{C} \mathrm{NMR}\left(125 \mathrm{MHz}, \mathrm{CDCl}_{3}\right) \delta_{\mathrm{C}}=173.8(\mathrm{C}=\mathrm{O})$, $138.6\left(\mathrm{C}_{\text {quat }}\right), 128.7\left(2 \times \mathrm{CH}_{\mathrm{Ar}}\right), 128.5\left(\mathrm{CH}_{\mathrm{Ar}}\right), 126.7\left(2 \times \mathrm{CH}_{\mathrm{Ar}}\right), 73.0(\mathrm{OH}-\mathrm{CH}), 62.4\left(\underline{\mathrm{CH}}_{2^{-}}\right.$ $\left.\mathrm{CH}_{3}\right), 14.2\left(\mathrm{CH}_{2}-\mathrm{CH}_{3}\right)$, general assignments were confirmed by ${ }^{1} \mathrm{H}^{-13} \mathrm{C} \mathrm{HSQC}$. LRMS-ESI: $\mathrm{m} / \mathrm{z}$ $=203[\mathrm{M}+\mathrm{Na}]^{+}$.

\section{Ethyl 2-(2,4-dimethoxyphenyl)-2-hydroxyacetate $(\mathbf{2 b})^{66,72}$}

The compound $\mathbf{2 b}$ was synthesized from ethyl glyoxylate $50 \%$ solution in toulene $(0.19 \mathrm{~mL}$, $1.0 \mathrm{mmol})$ and compound $1 \mathrm{a}(0.272 \mathrm{~g}, 1.5 \mathrm{mmol})$ according to general procedure 1 . The crude residue was purified by flash chromatography (Gradient: 8-10\% EtOAc in $n$-hexane) to afford the title compound as a pale yellow oil ( $0.209 \mathrm{~g}, 87.08 \%) . R_{f}=0.39$ (30\% EtOAc in $n$-hexane). ${ }^{1} \mathrm{H}$ NMR $\left(500 \mathrm{MHz}, \mathrm{DMSO}-d_{6}\right) \delta_{\mathrm{H}}=7.20\left(\mathrm{~d}, J=8.4 \mathrm{~Hz}, 1 \mathrm{H}, \mathrm{H}_{\mathrm{Ar}}\right), 6.54\left(\mathrm{~d}, J_{\text {meta }}=2.4 \mathrm{~Hz}, 1 \mathrm{H}\right.$, $\left.\mathrm{H}_{\mathrm{Ar}}\right), 6.51\left(\mathrm{dd}, J_{\text {ortho, meta }}=8.35,2.4 \mathrm{~Hz}, 1 \mathrm{H}, \mathrm{H}_{\mathrm{Ar}}\right), 5.66(\mathrm{~d}, J=6.05 \mathrm{~Hz}, 1 \mathrm{H}, \mathrm{OH}-\mathrm{C} \underline{\mathrm{H}}), 5.20(\mathrm{~d}$, $J=6.05 \mathrm{~Hz}, 1 \mathrm{H}, \mathrm{CH}-\mathrm{O} \underline{\mathrm{H}}), 4.09-4.02\left(\mathrm{~m}, 2 \mathrm{H}, \mathrm{C}_{2}-\mathrm{CH}_{3}\right), 3.75\left(\mathrm{~s}, 6 \mathrm{H}, 2 \times \mathrm{OCH}_{3}\right), 1.12(\mathrm{t}, J=$ $\left.7.1 \mathrm{~Hz}, 3 \mathrm{H}, \mathrm{CH}_{2}-\underline{\mathrm{H}}_{3}\right)$, general assignments were confirmed by ${ }^{1} \mathrm{H}-{ }^{1} \mathrm{H}$ gCOSY.${ }^{13} \mathrm{C}$ NMR (125 MHz, DMSO- $\left.d_{6}\right) \delta_{\mathrm{C}}=172.9(\mathrm{C}=\mathrm{O}), 160.3\left(\mathrm{C}_{\text {quat }}\right), 157.4\left(\mathrm{C}_{\text {quat }}\right), 128.7\left(\mathrm{CH}_{\mathrm{Ar}}\right), 120.6\left(\mathrm{C}_{\text {quat }}\right)$, 104.7 $\left(\mathrm{CH}_{\mathrm{Ar}}\right), 98.3\left(\mathrm{CH}_{\mathrm{Ar}}\right), 66.9(\mathrm{OH}-\mathrm{CH}), 60.0\left(\underline{\mathrm{CH}}_{2}-\mathrm{CH}_{3}\right), 55.5\left(\mathrm{OCH}_{3}\right), 55.2\left(\mathrm{OCH}_{3}\right), 14.1$ $\left(\mathrm{CH}_{2}-\underline{\mathrm{CH}}_{3}\right)$, general assignments were confirmed by ${ }^{1} \mathrm{H}_{-}{ }^{13} \mathrm{C}$ HSQC. LRMS-ESI: $m / z=263$ [M $+\mathrm{Na}]^{+}$ 


\section{5-Phenyl-1,3-oxazolidine-2,4-dione (10)}

The compound $\mathbf{1 0}$ was synthesized from compound 2a $(0.179 \mathrm{~g}, 0.9944 \mathrm{mmol})$ according to general procedure 2. The crude residue was purified by flash chromatography (Gradient: 15-20\% EtOAc in $n$-hexane) to afford the title compound as a white solid $(0.030 \mathrm{~g}, 17.04 \%)$. $R_{f}=0.34\left(30 \%\right.$ EtOAc in $n$-hexane). $\mathrm{Mp}=100-102^{\circ} \mathrm{C} .{ }^{1} \mathrm{H}$ NMR $\left(500 \mathrm{MHz}, \mathrm{DMSO}-d_{6}\right) \delta_{\mathrm{H}}=$ 12.15 (s, 1H, NH), 7.46-7.44 (m, 3H, $\left.\mathrm{H}_{\mathrm{Ar}}\right), 7.41-7.40$ (m, 2H, $\left.\mathrm{H}_{\mathrm{Ar}}\right), 6.04$ (s, 1H, O-CH-CO), general assignments were confirmed by ${ }^{1} \mathrm{H}-{ }^{1} \mathrm{H}$ gCOSY.${ }^{13} \mathrm{C}$ NMR $\left(125 \mathrm{MHz}\right.$, DMSO- $\left.d_{6}\right) \delta_{\mathrm{C}}=$ $173.5(\mathrm{C}=\mathrm{O}), 155.6(\mathrm{C}=\mathrm{O}), 132.8\left(\mathrm{C}_{\text {quat }}\right), 129.5\left(\mathrm{CH}_{\mathrm{Ar}}\right), 128.9\left(2 \times \mathrm{CH}_{\mathrm{Ar}}\right), 126.8\left(2 \times \mathrm{CH}_{\mathrm{Ar}}\right)$, 81.0 (O-ChH-CO), general assignments were confirmed by ${ }^{1} \mathrm{H}^{13} \mathrm{C}$ HSQC. LRMS-ESI: $m / z=$ $176[\mathrm{M}-\mathrm{H}]^{+}$. HRMS-ESI: $[\mathrm{M}-\mathrm{H}]^{+}$calcd for $\mathrm{C}_{9} \mathrm{H}_{6} \mathrm{NO}_{3}, 176.0342$, found 176.0352.

\section{5-(2,4-Dimethoxyphenyl)-1,3-oxazolidine-2,4-dione (11)}

The compound $\mathbf{1 1}$ was synthesized from compound $\mathbf{2 b}(0.19 \mathrm{~g}, 0.7908 \mathrm{mmol})$ according to general procedure 2 . The crude residue was purified by flash chromatography (Gradient: $4-5 \%$ $\mathrm{MeOH}$ in DCM) to afford the title compound as a white solid $(0.035 \mathrm{~g}, 18.71 \%) \cdot R_{f}=0.58(10 \%$ $\mathrm{MeOH}$ in DCM). Mp $=180-182^{\circ} \mathrm{C} .{ }^{1} \mathrm{H}$ NMR $\left(500 \mathrm{MHz}, \mathrm{DMSO}-d_{6}\right) \delta_{\mathrm{H}}=11.86(\mathrm{~s}, 1 \mathrm{H}, \mathrm{NH})$, $7.29\left(\mathrm{~d}, J_{\text {ortho }}=8.4 \mathrm{~Hz}, 1 \mathrm{H}, \mathrm{H}_{\mathrm{Ar}}\right), 6.63\left(\mathrm{~d}, J_{\text {meta }}=2.35 \mathrm{~Hz}, 1 \mathrm{H}, \mathrm{H}_{\mathrm{Ar}}\right), 6.56\left(\mathrm{dd}, J_{\text {ortho, meta }}=8.4\right.$, $\left.2.4 \mathrm{~Hz}, 1 \mathrm{H}, \mathrm{H}_{\mathrm{Ar}}\right), 5.89$ (s, 1H, O-CH-CO), 3.79 (s, 3H, $\left.\mathrm{OCH}_{3}\right), 3.74\left(\mathrm{~s}, 3 \mathrm{H}, \mathrm{OCH}_{3}\right)$, general assignments were confirmed by ${ }^{1} \mathrm{H}-{ }^{1} \mathrm{H}$ gCOSY. ${ }^{13} \mathrm{C}$ NMR $\left(125 \mathrm{MHz}, \mathrm{DMSO}-d_{6}\right) \delta_{\mathrm{C}}=174.3$ $(\mathrm{C}=\mathrm{O}), 162.4(\mathrm{C}=\mathrm{O}), 159.3\left(\mathrm{C}_{\text {quat }}\right), 155.9\left(\mathrm{C}_{\text {quat }}\right), 132.9\left(\mathrm{CH}_{\mathrm{Ar}}\right), 112.8\left(\mathrm{C}_{\text {quat }}\right), 105.1\left(\mathrm{CH}_{\mathrm{Ar}}\right), 99.1$ $\left(\mathrm{CH}_{\mathrm{Ar}}\right), 79.8(\mathrm{O}-\underline{\mathrm{C}} \mathrm{H}-\mathrm{CO}), 55.9\left(\mathrm{OCH}_{3}\right), 55.5\left(\mathrm{OCH}_{3}\right)$, general assignments were confirmed by ${ }^{1} \mathrm{H}-{ }^{13} \mathrm{C}$ HSQC. LRMS-ESI: $m / z=236[\mathrm{M}-\mathrm{H}]^{+}$. HRMS-ESI: $[\mathrm{M}+\mathrm{Na}]^{+}$calcd for $\mathrm{C}_{11} \mathrm{H}_{11} \mathrm{NNaO}_{5}, 260.0529$, found 260.0529 . 


\section{5-Phenyl-1,3-thiazolidine-2,4-dione (13)}

The compound $\mathbf{1 3}$ was synthesized from compound $\mathbf{2 a}(0.45 \mathrm{~g}, 2.5 \mathrm{mmol})$ according to general procedure 2. The crude residue was purified by flash chromatography (gradient: $10-15 \%$ EtOAc in $n$-hexane) to afford the title compound as a white solid $(0.020 \mathrm{~g}, 4.14 \%) . R_{f}=0.37$ (30\% EtOAc in $n$-hexane). $\mathrm{Mp}=134-136^{\circ} \mathrm{C} .{ }^{1} \mathrm{H}$ NMR $\left(500 \mathrm{MHz}, \mathrm{DMSO}-d_{6}\right) \delta_{\mathrm{H}}=13.55(\mathrm{~s}$, $1 \mathrm{H}, \mathrm{NH}), 7.49-7.47\left(\mathrm{~m}, 3 \mathrm{H}, \mathrm{H}_{\mathrm{Ar}}\right), 7.38-7.36\left(\mathrm{~m}, 2 \mathrm{H}, \mathrm{H}_{\mathrm{Ar}}\right), 6.27$ (s, 1H, S-CH-CO), general assignments were confirmed by ${ }^{1} \mathrm{H}-{ }^{1} \mathrm{H}$ gCOSY. ${ }^{13} \mathrm{C}$ NMR $\left(125 \mathrm{MHz}, \mathrm{DMSO}-d_{6}\right) \delta_{\mathrm{C}}=192.1$ $(\mathrm{C}=\mathrm{O}), 174.7(\mathrm{C}=\mathrm{O}), 132.5\left(\mathrm{C}_{\text {quat }}\right), 130.3\left(\mathrm{CH}_{\mathrm{Ar}}\right), 129.7\left(2 \times \mathrm{CH}_{\mathrm{Ar}}\right), 127.5\left(2 \times \mathrm{CH}_{\mathrm{Ar}}\right), 84.8(\mathrm{~S}-$ $\underline{\mathrm{C}} \mathrm{H}-\mathrm{CO}$ ), general assignments were confirmed by ${ }^{1} \mathrm{H}-{ }^{13} \mathrm{C}$ HSQC. LRMS-ESI: $m / z=192[\mathrm{M}-$ $\mathrm{H}]^{+}$. HRMS-ESI: $[\mathrm{M}-\mathrm{H}]^{+}$calcd for $\mathrm{C}_{9} \mathrm{H}_{6} \mathrm{NO}_{2} \mathrm{~S}, 192.0114$, found 192.0127.

\section{5-(2,4-Dimethoxyphenyl)-2-thioxo-1,3-oxazolidin-4-one (14')}

The compound 14' was synthesized from compound $\mathbf{2 b}(0.385 \mathrm{~g}, 1.604 \mathrm{mmol})$ according to general procedure 2. The crude residue was purified by flash chromatography (gradient: $10-20 \%$ EtOAc in $n$-hexane) to afford the title compound as a colorless oil $(0.013 \mathrm{~g}, 3.20 \%)$. ${ }^{1} \mathrm{H}$ NMR $\left(500 \mathrm{MHz}, \mathrm{DMSO}-d_{6}\right) \delta_{\mathrm{H}}=13.25(\mathrm{~s}, 1 \mathrm{H}, \mathrm{NH}), 7.31\left(\mathrm{~d}, J=8.45 \mathrm{~Hz}, 1 \mathrm{H}, \mathrm{H}_{\mathrm{Ar}}\right), 6.65$ $\left(\mathrm{d}, J=2.35 \mathrm{~Hz}, 1 \mathrm{H}, \mathrm{H}_{\mathrm{Ar}}\right), 6.59\left(\mathrm{dd}, J=8.35,2.4 \mathrm{~Hz}, 1 \mathrm{H}, \mathrm{H}_{\mathrm{Ar}}\right), 6.10(\mathrm{~s}, 1 \mathrm{H}, \mathrm{O}-\mathrm{CH}-\mathrm{CO}), 3.80(\mathrm{~s}$, $\left.3 \mathrm{H}, \mathrm{OCH}_{3}\right), 3.74\left(\mathrm{~s}, 3 \mathrm{H}, \mathrm{OCH}_{3}\right) .{ }^{13} \mathrm{C} \mathrm{NMR}\left(125 \mathrm{MHz}, \mathrm{DMSO}-d_{6}\right) \delta_{\mathrm{C}}=173.03(\mathrm{C}=\mathrm{O}), 160.4$ $(\mathrm{C}=\mathrm{S}), 157.5\left(\mathrm{C}_{\text {quat }}\right), 128.8\left(\mathrm{CH}_{\mathrm{Ar}}\right), 120.6\left(\mathrm{CH}_{\mathrm{Ar}}\right), 112.2\left(\mathrm{C}_{\text {quat }}\right), 104.8\left(\mathrm{CH}_{\mathrm{Ar}}\right), 98.4\left(\mathrm{C}_{\text {quat }}\right), 83.1$ (O-ㅡH-CO), $55.6\left(\mathrm{OCH}_{3}\right), 55.3\left(\mathrm{OCH}_{3}\right)$. LRMS-ESI: $m / z=252[\mathrm{M}-\mathrm{H}]^{+}$.

\section{5-(Phenylmethylidene)imidazolidine-2,4-dione (18)}

The compound 18 was synthesized from compound $\mathbf{3 a}(1.0 \mathrm{~g}, 9.423 \mathrm{mmol})$ according to general procedure 3. The crude residue was purified by flash chromatography (Gradient: $20-25 \%$ EtOAc in $n$-hexane) to afford the title compound as a yellow solid $(1.30 \mathrm{~g}, 73.44 \%) . R_{f}=0.17$ 
(30\% EtOAc in $n$-hexane). Mp $=270-275^{\circ} \mathrm{C}$, decomposition. ${ }^{1} \mathrm{H}$ NMR $\left(500 \mathrm{MHz}, \mathrm{DMSO}-d_{6}\right)$ $\delta_{\mathrm{H}}=7.61\left(\mathrm{~d}, J_{\text {ortho }}=7.25 \mathrm{~Hz}, 2 \mathrm{H}, \mathrm{H}_{\mathrm{Ar}}\right), 7.37\left(\mathrm{t}, J_{\text {ortho }}=7.85 \mathrm{~Hz}, 2 \mathrm{H}, \mathrm{H}_{\mathrm{Ar}}\right), 7.30-7.27(\mathrm{~m}, 1 \mathrm{H}$, $\left.\mathrm{H}_{\mathrm{Ar}}\right), 6.30(\mathrm{~s}, 1 \mathrm{H}, \mathrm{Ph}-\mathrm{CH}=\mathrm{C}), \mathrm{NH}$ protons are in exchange, general assignments were confirmed by ${ }^{1} \mathrm{H}-{ }^{1} \mathrm{H}$ gCOSY. ${ }^{13} \mathrm{C}$ NMR $\left(125 \mathrm{MHz}, \mathrm{DMSO}-d_{6}\right) \delta_{\mathrm{C}}=165.9(\mathrm{C}=\mathrm{O}), 156.0(\mathrm{C}=\mathrm{O}), 133.1$ $\left(\mathrm{C}_{\text {quat }}\right), 129.5\left(2 \times \mathrm{CH}_{\mathrm{Ar}}\right), 129.0\left(2 \times \mathrm{CH}_{\mathrm{Ar}}\right), 128.6\left(\mathrm{CH}_{\mathrm{Ar}}\right), 128.2\left(\mathrm{C}_{\text {quat }}\right), 108.5(\mathrm{Ph}-\underline{\mathrm{CH}}=\mathrm{C})$, general assignments were confirmed by ${ }^{1} \mathrm{H}^{13} \mathrm{C}$ HSQC. LRMS-ESI: $m / z=189[\mathrm{M}+\mathrm{H}]^{+}$. HRMS-ESI: $[\mathrm{M}+\mathrm{Na}]^{+}$calcd for $\mathrm{C}_{10} \mathrm{H}_{8} \mathrm{~N}_{2} \mathrm{NaO}_{2}, 211.0478$, found 211.0477.

\section{5-[(2,4-Dimethoxyphenyl)methylidene]imidazolidine-2,4-dione (19)}

The compound 19 was synthesized from compound $\mathbf{3 b}(1.0 \mathrm{~g}, 6.0175 \mathrm{mmol})$ according to general procedure 3. The crude residue was purified by flash chromatography (Gradient: $60-80 \%$ EtOAc in $n$-hexane) to afford the title compound as a yellow solid $(0.850 \mathrm{~g}, 56.97 \%)$. $R_{f}=0.55(50 \%$ EtOAc in $n$-hexane $) . \mathrm{Mp}=230-232^{\circ} \mathrm{C} .{ }^{1} \mathrm{H}$ NMR $\left(500 \mathrm{MHz}, \mathrm{DMSO}-d_{6}\right) \delta_{\mathrm{H}}=$ $7.56\left(\mathrm{~d}, J_{\text {ortho }}=8.45 \mathrm{~Hz}, 1 \mathrm{H}, \mathrm{H}_{\mathrm{Ar}}\right), 6.61-6.60\left(\mathrm{~m}, 2 \mathrm{H}, \mathrm{H}_{\mathrm{Ar}}\right.$ and $\left.\mathrm{Ph}-\mathrm{CH}-\mathrm{C}\right), 6.55\left(\mathrm{~d}, J_{\text {ortho }}=8.30\right.$ $\left.\mathrm{Hz}, 1 \mathrm{H}, \mathrm{H}_{\mathrm{Ar}}\right), 3.84\left(\mathrm{~s}, 3 \mathrm{H}, \mathrm{OCH}_{3}\right), 3.81\left(\mathrm{~s}, 3 \mathrm{H}, \mathrm{OCH}_{3}\right), \mathrm{NH}$ protons are in exchange, general assignments were confirmed by ${ }^{1} \mathrm{H}-{ }^{1} \mathrm{H}$ gCOSY.${ }^{13} \mathrm{C}$ NMR $\left(125 \mathrm{MHz}, \mathrm{DMSO}-d_{6}\right) \delta_{\mathrm{C}}=166.1$ $(\mathrm{C}=\mathrm{O}), 161.6(\mathrm{C}=\mathrm{O}), 159.1\left(\mathrm{C}_{\text {quat }}\right), 156.0\left(\mathrm{C}_{\text {quat }}\right), 130.6\left(\mathrm{CH}_{\mathrm{Ar}}\right), 126.5\left(\mathrm{C}_{\text {quat }}\right), 114.7\left(\mathrm{C}_{\text {quat }}\right)$, 106.0 $\left(\mathrm{CH}_{\mathrm{Ar}}\right), 103.5\left(\mathrm{CH}_{\mathrm{Ar}}\right), 98.7(\mathrm{Ph}-\underline{\mathrm{C}} \mathrm{H}=\mathrm{C}), 56.2\left(\mathrm{OCH}_{3}\right), 55.9\left(\mathrm{OCH}_{3}\right)$, general assignments were confirmed by ${ }^{1} \mathrm{H}^{-13} \mathrm{C}$ HSQC. LRMS-ESI: $m / z=249[\mathrm{M}+\mathrm{H}]^{+}$. HRMS-ESI: $[\mathrm{M}+\mathrm{H}]^{+}$ calcd for $\mathrm{C}_{12} \mathrm{H}_{13} \mathrm{~N}_{2} \mathrm{O}_{4}, 249.0870$, found 249.0869.

\section{5-Benzylimidazolidine-2,4-dione (20)}

The compound 20 was synthesized from compound $18(0.1 \mathrm{~g}, 0.5317 \mathrm{mmol})$ according to general procedure 4 . The crude residue was purified by flash chromatography (Gradient: $50-60 \%$ EtOAc in $n$-hexane) to afford the title compound as a white solid $(0.09 \mathrm{~g}, 89.10 \%) . R_{f}$ 
$=0.17(50 \%$ EtOAc in $n$-hexane $) . \mathrm{Mp}=191-193^{\circ} \mathrm{C} .{ }^{1} \mathrm{H}$ NMR $\left(500 \mathrm{MHz}, \mathrm{DMSO}-d_{6}\right) \delta_{\mathrm{H}}=$ $10.43(\mathrm{~s}, 1 \mathrm{H}, \mathrm{NH}), 7.91(\mathrm{~s}, 1 \mathrm{H}, \mathrm{NH}), 7.29-7.26\left(\mathrm{~m}, 2 \mathrm{H}, \mathrm{H}_{\mathrm{Ar}}\right), 7.23-7.21\left(\mathrm{~m}, 1 \mathrm{H}, \mathrm{H}_{\mathrm{Ar}}\right), 7.19-7.18$

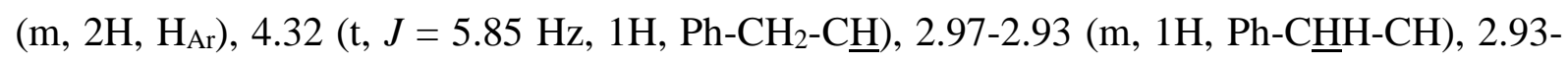
2.89 (m, 1H, Ph-CHㅍ- $\mathrm{CH})$, general assignments were confirmed by ${ }^{1} \mathrm{H}-{ }^{1} \mathrm{H}$ gCOSY.${ }^{13} \mathrm{C}$ NMR $\left(125 \mathrm{MHz}, \mathrm{DMSO}-d_{6}\right) \delta_{\mathrm{C}}=175.2(\mathrm{C}=\mathrm{O}), 156.2(\mathrm{C}=\mathrm{O}), 135.6\left(\mathrm{C}_{\text {quat }}\right), 129.7\left(2 \times \mathrm{CH}_{\mathrm{Ar}}\right), 128.1$

$\left(2 \times \mathrm{CH}_{\mathrm{Ar}}\right), 126.6\left(\mathrm{CH}_{\mathrm{Ar}}\right), 58.4\left(\mathrm{Ph}-\mathrm{CH}_{2}-\underline{\mathrm{CH}}\right), 36.4\left(\mathrm{Ph}-\underline{\mathrm{C}} \mathrm{H}_{2}-\mathrm{CH}\right)$, general assignments were confirmed by ${ }^{1} \mathrm{H}_{-}{ }^{13} \mathrm{C}$ HSQC. LRMS-ESI: $m / z=191[\mathrm{M}+\mathrm{H}]^{+}, 213[\mathrm{M}+\mathrm{Na}]^{+}$. HRMS-ESI: $[\mathrm{M}$ $+\mathrm{Na}]^{+}$calcd for $\mathrm{C}_{10} \mathrm{H}_{10} \mathrm{~N}_{2} \mathrm{NaO}_{2}, 213.0635$, found 213.0634.

\section{5-[(2,4-Dimethoxyphenyl)methyl]imidazolidine-2,4-dione (21)}

The compound 21 was synthesized from compound 19 (0.1 g, $0.4030 \mathrm{mmol})$ according to general procedure 4. The crude residue was purified by flash chromatography (Gradient: $30-40 \%$ EtOAc in $n$-hexane) to afford the title compound as a white solid $(0.055 \mathrm{~g}, 55.0 \%) . R_{f}$ $=0.13\left(50 \%\right.$ EtOAc in $n$-hexane). $\mathrm{Mp}=165-167^{\circ} \mathrm{C} .{ }^{1} \mathrm{H}$ NMR $\left(500 \mathrm{MHz}, \mathrm{DMSO}-d_{6}\right) \delta_{\mathrm{H}}=$ $10.49(\mathrm{~s}, 1 \mathrm{H}, \mathrm{NH}), 7.69(\mathrm{~s}, 1 \mathrm{H}, \mathrm{NH}), 7.02\left(\mathrm{~d}, J_{\text {ortho }}=8.25 \mathrm{~Hz}, 1 \mathrm{H}, \mathrm{H}_{\mathrm{Ar}}\right), 6.52\left(\mathrm{~d}, J_{\text {meta }}=2.4 \mathrm{~Hz}\right.$, $\left.1 \mathrm{H}, \mathrm{H}_{\mathrm{Ar}}\right), 6.44\left(\mathrm{dd}, J_{\text {ortho, meta }}=8.3,2.4 \mathrm{~Hz}, 1 \mathrm{H}, \mathrm{H}_{\mathrm{Ar}}\right), 4.19-4.16\left(\mathrm{~m}, 1 \mathrm{H}, \mathrm{Ph}_{-} \mathrm{CH}_{2}-\mathrm{C} \underline{\mathrm{H}}\right), 3.75(\mathrm{~s}$, $\left.3 \mathrm{H}, \mathrm{OCH}_{3}\right), 3.74\left(\mathrm{~s}, 3 \mathrm{H}, \mathrm{OCH}_{3}\right), 2.98(\mathrm{dd}, J=13.9,4.95 \mathrm{~Hz}, 1 \mathrm{H}, \mathrm{Ph}-\mathrm{C} \underline{H} \mathrm{H}-\mathrm{CH}), 2.65$ (dd, $J=$ 13.9, 7.45 Hz, 1H, Ph-CH$-\mathrm{CH})$, general assignments were confirmed by ${ }^{1} \mathrm{H}-{ }^{1} \mathrm{H}$ gCOSY.${ }^{13} \mathrm{C}$ NMR $\left(125 \mathrm{MHz}, \mathrm{DMSO}-d_{6}\right) \delta_{\mathrm{C}}=175.5(\mathrm{C}=\mathrm{O}), 159.6(\mathrm{C}=\mathrm{O}), 158.3\left(\mathrm{C}_{\text {quat }}\right), 157.3\left(\mathrm{C}_{\text {quat }}\right), 131.3$ $\left(\mathrm{CH}_{\mathrm{Ar}}\right), 116.4\left(\mathrm{C}_{\mathrm{quat}}\right), 104.4\left(\mathrm{CH}_{\mathrm{Ar}}\right), 98.2\left(\mathrm{CH}_{\mathrm{Ar}}\right), 57.6\left(\mathrm{Ph}-\mathrm{CH}_{2}-\underline{\mathrm{CH}}\right), 55.4\left(\mathrm{OCH}_{3}\right), 55.1$ $\left(\mathrm{OCH}_{3}\right), 31.6\left(\mathrm{Ph}-\underline{\mathrm{CH}}_{2}-\mathrm{CH}\right)$, general assignments were confirmed by ${ }^{1} \mathrm{H}^{-13} \mathrm{C}$ HSQC. LRMSESI: $m / z=251[\mathrm{M}+\mathrm{H}]^{+}, 273[\mathrm{M}+\mathrm{Na}]^{+}$. HRMS-ESI: $[\mathrm{M}+\mathrm{Na}]^{+}$calcd for $\mathrm{C}_{12} \mathrm{H}_{14} \mathrm{~N}_{2} \mathrm{NaO}_{4}$, 273.0846, found 273.0845.

5-[(2,4-Dimethoxyphenyl)methylidene]-2-sulfanylideneimidazolidin-4-one (26) 
The compound 26 was synthesized from compound $\mathbf{3 b}(1.0 \mathrm{~g}, 6.0175 \mathrm{mmol})$ according to general procedure 3. The crude residue was purified by flash chromatography (Gradient: $10-20 \%$ EtOAc in $n$-hexane) to afford the title compound as a yellow solid $(0.852 \mathrm{~g}, 53.52 \%)$. $R_{f}=0.25$ (30\% EtOAc in $n$-hexane). $\mathrm{Mp}=235-237^{\circ} \mathrm{C} .{ }^{1} \mathrm{H}$ NMR $\left(500 \mathrm{MHz}, \mathrm{DMSO}-d_{6}\right) \delta_{\mathrm{H}}=$ $12.23(\mathrm{~s}, 1 \mathrm{H}, \mathrm{NH}), 11.93(\mathrm{~s}, 1 \mathrm{H}, \mathrm{NH}), 7.74\left(\mathrm{~d}, J_{\text {ortho }}=8.65 \mathrm{~Hz}, 1 \mathrm{H}, \mathrm{H}_{\mathrm{Ar}}\right), 6.69(\mathrm{~s}, 1 \mathrm{H}, \mathrm{Ph}-$ $\mathrm{CH}=\mathrm{C}), 6.61\left(\mathrm{~d}, J_{\text {meta }}=2.35 \mathrm{~Hz}, 1 \mathrm{H}, \mathrm{H}_{\mathrm{Ar}}\right), 6.58\left(\mathrm{dd}, J_{\text {ortho, meta }}=8.6,2.4 \mathrm{~Hz}, 1 \mathrm{H}, \mathrm{H}_{\mathrm{Ar}}\right), 3.86(\mathrm{~s}$, $\left.3 \mathrm{H}, \mathrm{OCH}_{3}\right), 3.83\left(\mathrm{~s}, 3 \mathrm{H}, \mathrm{OCH}_{3}\right)$, general assignments were confirmed by ${ }^{1} \mathrm{H}-{ }^{1} \mathrm{H}$ gCOSY. ${ }^{13} \mathrm{C}$ NMR (125 MHz, DMSO- $\left.d_{6}\right) \delta_{\mathrm{C}}=178.1(\mathrm{C}=\mathrm{S}), 165.8(\mathrm{C}=\mathrm{O}), 162.1\left(\mathrm{C}_{\text {quat }}\right), 159.2\left(\mathrm{C}_{\text {quat }}\right), 131.3$ $\left(\mathrm{CH}_{\mathrm{Ar}}\right), 125.8\left(\mathrm{C}_{\text {quat }}\right), 113.7\left(\mathrm{C}_{\text {quat }}\right), 106.5(\mathrm{Ph}-\underline{\mathrm{CH}}=\mathrm{C}), 105.9\left(\mathrm{CH}_{\mathrm{Ar}}\right), 98.2\left(\mathrm{CH}_{\mathrm{Ar}}\right), 55.9\left(\mathrm{OCH}_{3}\right)$, $55.5\left(\mathrm{OCH}_{3}\right)$, general assignments were confirmed by ${ }^{1} \mathrm{H}_{-}{ }^{13} \mathrm{C}$ HSQC. LRMS-ESI: $m / z=265$ $[\mathrm{M}+\mathrm{H}]^{+}, 287[\mathrm{M}+\mathrm{Na}]^{+}$. HRMS (ESI): $[\mathrm{M}+\mathrm{H}]^{+}$calcd for $\mathrm{C}_{12} \mathrm{H}_{13} \mathrm{~N}_{2} \mathrm{O}_{3} \mathrm{~S}, 265.0641$, found 265.0641 .

\section{5-[(2,4-Dimethoxyphenyl)methyl]-2-sulfanylideneimidazolidin-4-one (27)}

To 5-benzylidene-2-sulfanylideneimidazolidin-4-one $26(0.1 \mathrm{~g}, 0.3787 \mathrm{mmol})$ in glacial acetic acid $(2 \mathrm{~mL})$ was added $\mathrm{Zn}$ dust $(0.272 \mathrm{~g}, 4.1657 \mathrm{mmol})$ at room temperature. The resultant reaction mixture was refluxed for 12-18 h. After completion of reaction (TLC), the reaction mixture was cooled down to $50{ }^{\circ} \mathrm{C}$, added $\mathrm{MeOH}(5 \times$ acetic acid qty.) refluxed for 5-10 min. The reaction mixture was then filtered through celite bed, washed with $\mathrm{MeOH}(15-20 \mathrm{~mL})$ and evaporated in vacuo. The crude residue was purified by flash chromatography (Gradient: $15-30 \%$ EtOAc in $n$-hexane) to afford the title compound as a yellow solid $(0.065 \mathrm{~g}, 65.0 \%)$. $R_{f}=0.58(50 \%$ EtOAc in $n$-hexane $) . \mathrm{Mp}=153-155^{\circ} \mathrm{C} .{ }^{1} \mathrm{H}$ NMR $\left(500 \mathrm{MHz}, \mathrm{DMSO}-d_{6}\right) \delta_{\mathrm{H}}=$ $11.50(\mathrm{~s}, 1 \mathrm{H}, \mathrm{NH}), 9.86(\mathrm{~s}, 1 \mathrm{H}, \mathrm{NH}), 7.01\left(\mathrm{~d}, J_{\text {ortho }}=8.3 \mathrm{~Hz}, 1 \mathrm{H}, \mathrm{H}_{\mathrm{Ar}}\right), 6.51\left(\mathrm{~d}, J_{\text {meta }}=2.4 \mathrm{~Hz}\right.$, $\left.1 \mathrm{H}, \mathrm{H}_{\mathrm{Ar}}\right), 6.43\left(\mathrm{dd}, J_{\text {ortho, meta }}=8.3,2.45 \mathrm{~Hz}, 1 \mathrm{H}, \mathrm{H}_{\mathrm{Ar}}\right), 4.40-4.38\left(\mathrm{~m}, 1 \mathrm{H}, \mathrm{Ph}-\mathrm{CH}_{2}-\mathrm{C} \underline{\mathrm{H}}\right), 3.76(\mathrm{~s}$, $\left.3 \mathrm{H}, \mathrm{OCH}_{3}\right), 3.74\left(\mathrm{~s}, 3 \mathrm{H}, \mathrm{OCH}_{3}\right), 2.96(\mathrm{dd}, J=14.05,5.65 \mathrm{~Hz}, 1 \mathrm{H}, \mathrm{Ph}-\mathrm{C} \underline{\mathrm{HH}}-\mathrm{CH}), 2.78(\mathrm{dd}, J=$ 
14.05, $6.65 \mathrm{~Hz}, 1 \mathrm{H}, \mathrm{Ph}-\mathrm{CH} \underline{\mathrm{H}}-\mathrm{CH})$, general assignments were confirmed by ${ }^{1} \mathrm{H}-{ }^{1} \mathrm{H}$ gCOSY.${ }^{13} \mathrm{C}$ NMR (125 MHz, DMSO- $\left.d_{6}\right) \delta_{\mathrm{C}}=182.3(\mathrm{C}=\mathrm{S}), 176.0(\mathrm{C}=\mathrm{O}), 159.8\left(\mathrm{C}_{\text {quat }}\right), 158.4\left(\mathrm{C}_{\text {quat }}\right), 131.5$ $\left(\mathrm{CH}_{\mathrm{Ar}}\right), 115.7\left(\mathrm{C}_{\text {quat }}\right), 104.5\left(\mathrm{CH}_{\mathrm{Ar}}\right), 98.3\left(\mathrm{CH}_{\mathrm{Ar}}\right), 60.7\left(\mathrm{Ph}-\mathrm{CH}_{2}-\underline{\mathrm{CH}}\right), 55.5\left(\mathrm{OCH}_{3}\right), 55.2$ $\left(\mathrm{OCH}_{3}\right), 30.8\left(\mathrm{Ph}-\mathrm{CH}_{2}-\mathrm{CH}\right)$, general assignments were confirmed by ${ }^{1} \mathrm{H}_{-}{ }^{13} \mathrm{C}$ HSQC. LRMSESI: $m / z=267[\mathrm{M}+\mathrm{H}]^{+}, 289[\mathrm{M}+\mathrm{Na}]^{+}$. HRMS-ESI: $[\mathrm{M}+\mathrm{H}]^{+}$calcd for $\mathrm{C}_{12} \mathrm{H}_{15} \mathrm{~N}_{2} \mathrm{O}_{3} \mathrm{~S}$, 267.0798, found 267.0798. Compound $27^{\prime}$ 'was subsequently identified as a $\sim 5 \%$ impurity in 27.

\section{5-(Phenylmethylidene)-2-sulfanylidene-1,3-thiazolidin-4-one (22)}

The compound 22 was synthesized from compound 3a (0.5 g, $4.7116 \mathrm{mmol})$ according to general procedure 5. The crude residue was recrystallised from EtOH to afford the title compound as a yellow solid $(0.6 \mathrm{~g}, 57.63 \%) . R_{f}=0.54$ (30\% EtOAc in $n$-hexane). $\mathrm{Mp}=$ 204-206 ${ }^{\circ} \mathrm{C} .{ }^{1} \mathrm{H}$ NMR $\left(500 \mathrm{MHz}, \mathrm{DMSO}-d_{6}\right) \delta_{\mathrm{H}}=13.84(\mathrm{~s}, 1 \mathrm{H}, \mathrm{NH}), 7.64(\mathrm{~s}, 1 \mathrm{H}, \mathrm{Ph}-\mathrm{CH}=\mathrm{C})$, 7.60-7.59 (m, 2H, $\left.\mathrm{H}_{\mathrm{Ar}}\right), 7.55-7.48\left(\mathrm{~m}, 3 \mathrm{H}, \mathrm{H}_{\mathrm{Ar}}\right)$, general assignments were confirmed by ${ }^{1} \mathrm{H}-{ }^{1} \mathrm{H}$ gCOSY. ${ }^{13} \mathrm{C}$ NMR (125 MHz, DMSO- $\left.d_{6}\right) \delta_{\mathrm{C}}=195.7(\mathrm{C}=\mathrm{S}), 169.4(\mathrm{C}=\mathrm{O}), 133.0\left(\mathrm{C}_{\text {quat }}\right), 131.6$ $(\mathrm{Ph}-\underline{\mathrm{CH}}=\mathrm{C}), 130.7\left(\mathrm{CH}_{\mathrm{Ar}}\right), 130.5\left(2 \times \mathrm{CH}_{\mathrm{Ar}}\right), 129.4\left(2 \times \mathrm{CH}_{\mathrm{Ar}}\right), 125.5\left(\mathrm{C}_{\text {quat }}\right)$, general assignments were confirmed by ${ }^{1} \mathrm{H}^{-13} \mathrm{C}$ HSQC. LRMS-ESI: $m / z=220[\mathrm{M}-\mathrm{H}]^{+}$. HRMS-ESI: $[\mathrm{M}-\mathrm{H}]^{+}$calcd for $\mathrm{C}_{10} \mathrm{H}_{6} \mathrm{NOS}_{2}, 219.9885$, found 219.9897 .

\section{5-[(2,4-Dimethoxyphenyl)methylidene]-2-sulfanylidene-1,3-thiazolidin-4-one (23)}

The compound $\mathbf{2 3}$ was synthesized from compound $\mathbf{3 b}(0.5 \mathrm{~g}, 3.008 \mathrm{mmol})$ according to general procedure 5. The crude residue was recrystallised from EtOH to afford the title compound as a yellow solid $(0.7 \mathrm{~g}, 82.84 \%) . R_{f}=0.31$ (30\% EtOAc in $n$-hexane). $\mathrm{Mp}=273-275^{\circ} \mathrm{C}$, decomposition. ${ }^{1} \mathrm{H}$ NMR (500 MHz, DMSO- $\left.d_{6}\right) \delta_{\mathrm{H}}=13.65(\mathrm{~s}, 1 \mathrm{H}, \mathrm{NH}), 7.74(\mathrm{~s}, 1 \mathrm{H}, \mathrm{Ph}-$ $\mathrm{CH}=\mathrm{C}), 7.33\left(\mathrm{~d}, J_{\text {ortho }}=8.65 \mathrm{~Hz}, 1 \mathrm{H}, \mathrm{H}_{\mathrm{Ar}}\right), 6.71\left(\mathrm{dd}, J_{\text {ortho, meta }}=8.65,2.3 \mathrm{~Hz}, 1 \mathrm{H}, \mathrm{H}_{\mathrm{Ar}}\right), 6.68(\mathrm{~s}$, 
$\left.1 \mathrm{H}, \mathrm{H}_{\mathrm{Ar}}\right), 3.90\left(\mathrm{~s}, 3 \mathrm{H}, \mathrm{OCH}_{3}\right), 3.85\left(\mathrm{~s}, 3 \mathrm{H}, \mathrm{OCH}_{3}\right)$, general assignments were confirmed by ${ }^{1} \mathrm{H}-$ ${ }^{1} \mathrm{H}$ gCOSY. ${ }^{13} \mathrm{C}$ NMR $\left(125 \mathrm{MHz}, \mathrm{DMSO}-d_{6}\right) \delta_{\mathrm{C}}=195.8(\mathrm{C}=\mathrm{S}), 169.5(\mathrm{C}=\mathrm{O}), 163.6\left(\mathrm{C}_{\text {quat }}\right)$, $160.0\left(\mathrm{C}_{\text {quat }}\right), 131.4\left(\mathrm{CH}_{\mathrm{Ar}}\right), 127.0(\mathrm{Ph}-\underline{\mathrm{C}} \mathrm{H}=\mathrm{C}), 121.7\left(\mathrm{C}_{\text {quat }}\right), 114.3\left(\mathrm{C}_{\text {quat }}\right), 106.9\left(\mathrm{CH}_{\mathrm{Ar}}\right), 98.6$ $\left(\mathrm{CH}_{\mathrm{Ar}}\right), 55.9\left(\mathrm{OCH}_{3}\right), 55.7\left(\mathrm{OCH}_{3}\right)$, general assignments were confirmed by ${ }^{1} \mathrm{H}^{-13} \mathrm{C}$ HSQC. LRMS-ESI: $m / z=280[\mathrm{M}-\mathrm{H}]^{+}$. HRMS-ESI: $[\mathrm{M}-\mathrm{H}]^{+}$calcd for $\mathrm{C}_{12} \mathrm{H}_{10} \mathrm{NO}_{3} \mathrm{~S}_{2}, 280.0097$, found 280.0107 .

\section{5-Benzyl-2-sulfanylidene-1,3-thiazolidin-4-one (24)}

The compound 24 was synthesized from compound $22(0.1 \mathrm{~g}, 0.4524 \mathrm{mmol})$ according to general procedure 6. The crude residue was purified by flash chromatography (Gradient: $15-20 \%$ EtOAc in $n$-hexane) to afford the title compound as a white solid (0.021 g, $21.0 \%)$. $R_{f}=0.34(30 \%$ EtOAc in $n$-hexane $) . \mathrm{Mp}=119-121{ }^{\circ} \mathrm{C} .{ }^{1} \mathrm{H}$ NMR $\left(500 \mathrm{MHz}, \mathrm{DMSO}-d_{6}\right) \delta_{\mathrm{H}}=$ $13.16(\mathrm{~s}, 1 \mathrm{H}, \mathrm{NH}), 7.33-7.23\left(\mathrm{~m}, 5 \mathrm{H}, \mathrm{H}_{\mathrm{Ar}}\right), 5.04\left(\mathrm{dd}, J=8.9,4.6 \mathrm{~Hz}, 1 \mathrm{H}, \mathrm{Ph}_{-} \mathrm{CH}_{2}-\mathrm{C} \underline{\mathrm{H}}\right), 3.37$ (dd, $J=14.1,4.45 \mathrm{~Hz}, 1 \mathrm{H}, \mathrm{Ph}-\mathrm{C} \underline{H} H-\mathrm{CH}), 3.17$ (dd, $J=14.1,9.1 \mathrm{~Hz}, 1 \mathrm{H}, \mathrm{Ph}-\mathrm{CH} \underline{H}-\mathrm{CH})$, general assignments were confirmed by ${ }^{1} \mathrm{H}-{ }^{1} \mathrm{H}$ gCOSY.${ }^{13} \mathrm{C}$ NMR $\left(125 \mathrm{MHz}, \mathrm{DMSO}-d_{6}\right) \delta_{\mathrm{C}}=203.3$ $(\mathrm{C}=\mathrm{S}), 177.9(\mathrm{C}=\mathrm{O}), 136.6\left(\mathrm{C}_{\text {quat }}\right), 129.2\left(2 \times \mathrm{CH}_{\mathrm{Ar}}\right), 128.5\left(2 \times \mathrm{CH}_{\mathrm{Ar}}\right), 127.1\left(\mathrm{CH}_{\mathrm{Ar}}\right), 55.7(\mathrm{Ph}-$ $\left.\mathrm{CH}_{2}-\underline{\mathrm{CH}}\right), 36.5$ ( $\left.\mathrm{Ph}-\underline{\mathrm{CH}_{2}-\mathrm{CH}}\right)$, general assignments were confirmed by ${ }^{1} \mathrm{H}^{-}{ }^{13} \mathrm{C}$ HSQC. LRMSESI: $m / z=222[\mathrm{M}-\mathrm{H}]^{+}$. HRMS-ESI: $[\mathrm{M}-\mathrm{H}]^{+}$calcd for $\mathrm{C}_{10} \mathrm{H}_{8} \mathrm{NOS}_{2}, 222.0042$, found 222.0054 .

\section{5-[(2,4-Dimethoxyphenyl)methyl]-2-sulfanylidene-1,3-thiazolidin-4-one (25)}

The compound 25 was synthesized from compound $23(0.2 \mathrm{~g}, 0.7117 \mathrm{mmol})$ according to general procedure 6 . The crude residue was purified by flash chromatography (Gradient: $12-15 \%$ EtOAc in $n$-hexane) to afford the title compound as a yellow solid $(0.095 \mathrm{~g}, 47.26 \%)$. $R_{f}=0.53\left(30 \%\right.$ EtOAc in $n$-hexane). $\mathrm{Mp}=160-162^{\circ} \mathrm{C} .{ }^{1} \mathrm{H}$ NMR $\left(500 \mathrm{MHz}, \mathrm{DMSO}-d_{6}\right) \delta_{\mathrm{H}}=$ 
$13.15(\mathrm{~s}, 1 \mathrm{H}, \mathrm{NH}), 7.04\left(\mathrm{~d}, J_{\text {ortho }}=8.25 \mathrm{~Hz}, 1 \mathrm{H}, \mathrm{H}_{\mathrm{Ar}}\right), 6.54\left(\mathrm{~d}, J_{\text {meta }}=2.4 \mathrm{~Hz}, 1 \mathrm{H}, \mathrm{H}_{\mathrm{Ar}}\right), 6.46$ $\left(\mathrm{dd}, J_{\text {ortho, meta }}=8.3,2.4 \mathrm{~Hz}, 1 \mathrm{H}, \mathrm{H}_{\mathrm{Ar}}\right), 4.90\left(\mathrm{dd}, J=9.6,4.85 \mathrm{~Hz}, 1 \mathrm{H}, \mathrm{Ph}_{-} \mathrm{CH}_{2}-\mathrm{C} \underline{\mathrm{H}}\right), 3.77(\mathrm{~s}, 3 \mathrm{H}$, $\left.\mathrm{OCH}_{3}\right), 3.74\left(\mathrm{~s}, 3 \mathrm{H}, \mathrm{OCH}_{3}\right), 3.36(\mathrm{dd}, J=13.95,4.85 \mathrm{~Hz}, 1 \mathrm{H}, \mathrm{Ph}-\mathrm{C} \underline{\mathrm{H}} \mathrm{H}-\mathrm{CH}), 2.95(\mathrm{dd}, J=14.0$, $9.6 \mathrm{~Hz}, 1 \mathrm{H}, \mathrm{Ph}-\mathrm{CH} \underline{\mathrm{H}}-\mathrm{CH})$, general assignments were confirmed by ${ }^{1} \mathrm{H}-{ }^{1} \mathrm{H}$ gCOSY. ${ }^{13} \mathrm{C}$ NMR $\left(125 \mathrm{MHz}, \mathrm{DMSO}-d_{6}\right) \delta_{\mathrm{C}}=203.6(\mathrm{C}=\mathrm{S}), 178.2(\mathrm{C}=\mathrm{O}), 160.0\left(\mathrm{C}_{\text {quat }}\right), 158.1\left(\mathrm{C}_{\text {quat }}\right), 130.8$ $\left(\mathrm{CH}_{\mathrm{Ar}}\right), 116.9\left(\mathrm{C}_{\text {quat }}\right), 104.6\left(\mathrm{CH}_{\mathrm{Ar}}\right), 98.4\left(\mathrm{CH}_{\mathrm{Ar}}\right), 55.4\left(\mathrm{OCH}_{3}\right), 55.2\left(\mathrm{OCH}_{3}\right), 54.8\left(\mathrm{Ph}-\mathrm{CH}_{2}-\right.$ $\underline{\mathrm{CH}}), 31.6\left(\mathrm{Ph}-\underline{\mathrm{CH}}_{2}-\mathrm{CH}\right)$, general assignments were confirmed by ${ }^{1} \mathrm{H}^{-}{ }^{13} \mathrm{C}$ HSQC. LRMS-ESI: $m / z=282[\mathrm{M}-\mathrm{H}]^{+}$. HRMS-ESI: $[\mathrm{M}-\mathrm{H}]^{+}$calcd for $\mathrm{C}_{12} \mathrm{H}_{12} \mathrm{NO}_{3} \mathrm{~S}_{2}, 282.0253$, found 282.0263.

\section{5-[(2,4-Dimethoxyphenyl)methylidene]-1,3-thiazolidine-2,4-dione (16)}

The compound 16 was synthesized from compound $\mathbf{3 b}(0.5 \mathrm{~g}, 3.008 \mathrm{mmol})$ according to general procedure 5. The crude residue was recrystallised from EtOH to afford the title compound as a yellow solid $(0.56 \mathrm{~g}, 70.26 \%) . R_{f}=0.60$ (30\% EtOAc in $n$-hexane). $\mathrm{Mp}=240-242^{\circ} \mathrm{C}$, decomposition. ${ }^{1} \mathrm{H}$ NMR $\left(500 \mathrm{MHz}, \mathrm{DMSO}-d_{6}\right) \delta_{\mathrm{H}}=12.43(\mathrm{~s}, 1 \mathrm{H}, \mathrm{NH}), 7.92(\mathrm{~s}, 1 \mathrm{H}, \mathrm{Ph}-$ $\mathrm{CH}=\mathrm{C}), 7.33\left(\mathrm{~d}, J_{\text {ortho }}=8.6 \mathrm{~Hz}, 1 \mathrm{H}, \mathrm{H}_{\mathrm{Ar}}\right), 6.70\left(\mathrm{dd}, J_{\text {ortho, meta }}=8.65,2.35 \mathrm{~Hz}, 1 \mathrm{H}, \mathrm{H}_{\mathrm{Ar}}\right), 6.67(\mathrm{~d}$, $\left.J_{\text {meta }}=2.25 \mathrm{~Hz}, 1 \mathrm{H}, \mathrm{H}_{\mathrm{Ar}}\right), 3.89\left(\mathrm{~s}, 3 \mathrm{H}, \mathrm{OCH}_{3}\right), 3.84\left(\mathrm{~s}, 3 \mathrm{H}, \mathrm{OCH}_{3}\right)$, general assignments were confirmed by ${ }^{1} \mathrm{H}-{ }^{1} \mathrm{H}$ gCOSY. ${ }^{13} \mathrm{C}$ NMR (125 MHz, DMSO- $\left.d_{6}\right) \delta_{\mathrm{C}}=168.2(\mathrm{C}=\mathrm{O}), 167.6(\mathrm{C}=\mathrm{O})$, $163.1\left(\mathrm{C}_{\text {quat }}\right), 159.8\left(\mathrm{C}_{\text {quat }}\right), 130.1\left(\mathrm{CH}_{\mathrm{Ar}}\right), 126.5(\mathrm{Ph}-\underline{\mathrm{CH}}=\mathrm{C}), 119.9\left(\mathrm{C}_{\text {quat }}\right), 114.3\left(\mathrm{C}_{\text {quat }}\right), 106.5$ $\left(\mathrm{CH}_{\mathrm{Ar}}\right), 98.6\left(\mathrm{CH}_{\mathrm{Ar}}\right), 55.9\left(\mathrm{OCH}_{3}\right), 55.6\left(\mathrm{OCH}_{3}\right)$, general assignments were confirmed by ${ }^{1} \mathrm{H}-$ ${ }^{13}$ C HSQC. LRMS-ESI: $m / z=266[\mathrm{M}+\mathrm{H}]^{+}, 288[\mathrm{M}+\mathrm{Na}]^{+}$. HRMS-ESI: $[\mathrm{M}+\mathrm{H}]^{+}$calcd for $\mathrm{C}_{12} \mathrm{H}_{12} \mathrm{NO}_{4} \mathrm{~S}, 266.0482$, found 266.0481 .

\section{5-[(2,4-Dimethoxyphenyl)methyl]-1,3-thiazolidine-2,4-dione (17)}

The compound 17 was synthesized from compound 16 (0.15 g, $0.5659 \mathrm{mmol})$ according to general procedure 6 . The crude residue was purified by flash chromatography (Gradient: 
$15-20 \%$ EtOAc in $n$-hexane) to afford the title compound as $(0.060 \mathrm{~g}, 39.73 \%) . R_{f}=0.33(30 \%$ EtOAc in $n$-hexane). $\mathrm{Mp}=169-171{ }^{\circ} \mathrm{C} .{ }^{1} \mathrm{H}$ NMR $\left(500 \mathrm{MHz}, \mathrm{DMSO}-d_{6}\right) \delta_{\mathrm{H}}=12.01(\mathrm{~s}, 1 \mathrm{H}$, $\mathrm{NH}), 7.04\left(\mathrm{~d}, J_{\text {ortho }}=8.3 \mathrm{~Hz}, 1 \mathrm{H}, \mathrm{H}_{\mathrm{Ar}}\right), 6.54\left(\mathrm{~d}, J_{\text {meta }}=2.4 \mathrm{~Hz}, 1 \mathrm{H}, \mathrm{H}_{\mathrm{Ar}}\right), 6.46\left(\mathrm{dd}, J_{\text {ortho, meta }}=\right.$

8.3, $\left.2.4 \mathrm{~Hz}, 1 \mathrm{H}, \mathrm{H}_{\mathrm{Ar}}\right), 4.78\left(\mathrm{dd}, J=10.0,4.55 \mathrm{~Hz}, 1 \mathrm{H}, \mathrm{Ph}_{-\mathrm{CH}_{2}-\mathrm{CH}}\right), 3.78$ (s, 3H, $\left.\mathrm{OCH}_{3}\right), 3.74$ (s, 3H, $\left.\mathrm{OCH}_{3}\right), 3.40$ (dd, $\left.J=13.9,4.5 \mathrm{~Hz}, 1 \mathrm{H}, \mathrm{Ph}-\mathrm{C} \underline{\mathrm{H}} \mathrm{H}-\mathrm{CH}\right), 2.87$ (dd, $J=13.9,10.0 \mathrm{~Hz}, 1 \mathrm{H}$, $\mathrm{Ph}-\mathrm{CH} \underline{\mathrm{H}}-\mathrm{CH})$, general assignments were confirmed by ${ }^{1} \mathrm{H}-{ }^{1} \mathrm{H}$ gCOSY. ${ }^{13} \mathrm{C}$ NMR $(125 \mathrm{MHz}$, DMSO- $\left.d_{6}\right) \delta_{\mathrm{C}}=175.9(\mathrm{C}=\mathrm{O}), 171.8(\mathrm{C}=\mathrm{O}), 159.9\left(\mathrm{C}_{\text {quat }}\right), 158.2\left(\mathrm{C}_{\text {quat }}\right), 130.8\left(\mathrm{CH}_{\mathrm{Ar}}\right), 117.1$ ( $\left.\mathrm{C}_{\text {quat }}\right), 104.5\left(\mathrm{CH}_{\mathrm{Ar}}\right), 98.4\left(\mathrm{CH}_{\mathrm{Ar}}\right), 55.4\left(\mathrm{OCH}_{3}\right), 55.1\left(\mathrm{OCH}_{3}\right), 51.8\left(\mathrm{Ph}-\mathrm{CH}_{2}-\underline{\mathrm{CH}}\right), 32.2(\mathrm{Ph}-$ $\left.\underline{\mathrm{CH}}_{2}-\mathrm{CH}\right)$, general assignments were confirmed by ${ }^{1} \mathrm{H}_{-}{ }^{13} \mathrm{C}$ HSQC. LRMS-ESI: $m / z=268[\mathrm{M}+$ $\mathrm{H}]^{+}, 290[\mathrm{M}+\mathrm{Na}]^{+}$. HRMS-ESI: $[\mathrm{M}+\mathrm{Na}]^{+}$calcd for $\mathrm{C}_{12} \mathrm{H}_{13} \mathrm{NNaO}_{4} \mathrm{~S}, 290.0458$, found 290.0458.

\section{Mass Spectrometry}

Prior to mass spectrometric analysis hCA II protein was concentrated and buffer exchanged into $10 \mathrm{mM} \mathrm{NH} 4 \mathrm{OAc}$ pH 7.0 using Amicon Ultra 0.5 centrifugal filters (Merck Millipore, Sydney, NSW, Australia). In detail, $500 \mu \mathrm{L}$ of the initial protein solution was loaded on the filter and centrifuged at $14,000 \times \mathrm{g}$ for $15 \mathrm{~min}$ at $4{ }^{\circ} \mathrm{C}$ on a Heraeus Pico 21 benchtop centrifuge (Thermo Fisher Scientific Australia Pty Ltd). The flow through was discarded and the concentrate resuspended in $450 \mu \mathrm{L}$ of $10 \mathrm{mM} \mathrm{NH}_{4} \mathrm{OAc} \mathrm{pH}$ 7.0. This process was repeated four times in order to minimise residual salt in the protein sample that may interfere with protein ionisation. The final concentrate was recovered by spinning at $3,000 \times \mathrm{g}$ for $1 \mathrm{~min}$ according to the manufacturers protocol. Concentration of the proteins was verified for CA II using the absorption at $280 \mathrm{~nm}$ combined with an extinction coefficient of $50.42 \times 10^{3} \mathrm{M}^{-1} \mathrm{~cm}^{-1}$ and 
adjusted to a final concentration of $15 \mu \mathrm{M}$ with $10 \mathrm{mM} \mathrm{NH}_{4} \mathrm{OAc}, \mathrm{pH}$ 7.0. All test fragments were prepared and stored as $5 \mathrm{mM}$ stock solutions in DMSO.

For experiments with equimolar concentration of protein and fragment, immediately before the mass spectrometric analysis, fragments were diluted in $10 \mathrm{mM} \mathrm{NH}_{4} \mathrm{OAc} 7.0 \mathrm{pH}$ to a final concentration of $15 \mu \mathrm{M}(0.3 \%$ DMSO $)$. hCA II (2.5 $\mu \mathrm{L}$ of $15 \mu \mathrm{M}$ stock) was mixed with fragment solution $(2.5 \mu \mathrm{L}$ of $15 \mu \mathrm{M}$ stock). For nanoESI-MS titration experiments, $0.5 \mu \mathrm{L}$ of the required fragment concentration in DMSO were prepared in assay-ready 96-well microplates by Compounds Australia (www.compoundsaustralia.com). Prior to analysis 14.5 $\mu \mathrm{L}$ of protein $\left(15 \mu \mathrm{M}, 10 \mathrm{mM} \mathrm{NH} \mathrm{N}_{4} \mathrm{OAc}\right)$ was added to each fragment containing microplate well (final sample 3.3\% DMSO). The protein:fragment sample solutions were mixed, then incubated for $10 \mathrm{~min}$ at room temperature before nanoESI-MS analysis. The incubation time was selected following time series test experiments which showed that no change in binding is observed after 10 min. FTICR-MS calibration using perfluorohexanoic acid (PFHA) was performed daily while quality control runs of pure CA II were performed before every batch of screening. For nanoESI-MS analysis samples were infused into a Bruker solariX $\mathrm{XR}^{\mathrm{TM}} 12.0$ Tesla Fourier Transform Ion Cyclotron Resonance (FT-ICR) mass spectrometer (FT-ICR MS) fitted with a ParaCell ${ }^{\mathrm{TM}}$ (Bruker Daltonics Inc., Billerica, MA) using a Triversa Nanomate (Advion BioSciences, Ithaca, NY, USA) automated nanoESI interface fitted with a 5 micron HD A ESI Chip (Advion BioSciences, Ithaca, NY, USA). Spray conditions were optimized for signal intensity, signal to noise ratio and spray duration. Positive ion ESI was used with a capillary voltage of $1.2 \mathrm{kV}$ and a nitrogen nebulizing gas pressure of 0.4 psi. The FT-ICR mass spectrometer parameters were optimised to maximise signal intensity whilst ensuring gentle enough conditions in order to retain the proteins in a native-like state and avoid in-source 
dissociation. In detail, data were acquired for at least 45 scans, over the range of $m / z 500-10,000$ with the quadrupole set at $\mathrm{m} / \mathrm{z} 600$ while a Skimmer 1 voltage of $30 \mathrm{~V}$, a Drying Gas Temperature of $100{ }^{\circ} \mathrm{C}$, a Nebulizer Gas Flow Rate of 2 bar, a Capillary Voltage of 3,500 V, a Spray Shield of $500 \mathrm{~V}$, a Collision Voltage (Entrance) of -3.0 V, a DC Extract Bias of 0.1 V, a Collision Cell RF of 2,000 Vpp, an Ion Accumulation Time of $0.001 \mathrm{sec}$ and a Flight Time of $2.1 \mathrm{msec}$ were used. Mass spectra were processed with Bruker Compass DataAnalysis 4.2 (Bruker Daltonics Inc., Billerica, MA). For the peak determination and intensity calculation, SNAP algorithm version 2.0 was used with a signal to noise threshold set at 3 and quality factor threshold set at 0.5 .

The FAMs for each fragment concentration was assigned as the ratio of the measured intensity of the fragment-bound protein $\mathrm{I}_{(\mathrm{P}: \mathrm{F})}$ peak to the sum of the unbound protein $\mathrm{I}_{(\mathrm{P})}$ and fragmentbound protein $\mathrm{I}_{(\mathrm{P}: \mathrm{F})}$ peaks for each spectrum, expressed as a percentage (Equation 1). Unbound protein $\mathrm{I}_{(\mathrm{P})}$ included both free protein and protein bound to acetate, the latter complex is preserved due to the very gentle electrospray ionisation conditions employed.

$$
\mathrm{FA}_{M S}=\frac{\mathrm{I}_{[\mathrm{P}: \mathrm{F}]}}{\mathrm{I}_{[\mathrm{P}: \mathrm{F}]}+\mathrm{I}_{[P]}} \times 100 \% \quad \quad(\text { Equation } 1)
$$

All three observed charge states $(+9,+10$ and +11$)$ where utilised for the FAMs calculations and compared to $\mathrm{FA}_{\mathrm{MS}}$ calculations using the predominant charge state $(+10)$. For the analyses of the saturation binding experiments we employed the nonlinear Hill model ${ }^{73}$ The calculation of $\mathrm{K}_{\mathrm{D}}$ value as well as curve fitting were performed by applying the Specific binding with Hill Slope equation in GraphPad Prism 7.01 (Equation 2), also using all three observed charge states $(+9,+10$ and +11$)$ and the single, predominant charge state $(+10)$ for comparison. 


$$
\frac{\text { Bound }}{\text { TotalProtein }}=\operatorname{Bmax} * \frac{\text { FragmentConcentration }^{\mathrm{h}}}{\mathrm{Kd}^{\mathrm{h}}+\text { FragmentConcentration }^{\mathrm{h}}} \text { (Equation 2) }
$$

In equation $2 B \max$ corresponds to the maximum specific binding, $K d$ to the fragment concentration needed to achieve a half-maximum binding at equilibrium and $h$ to the Hill slope, which equals 1.0 when a monomer fragment binds to a single site of the protein.

\section{SPR}

Fragments were screened against biotinylated CA II with SPR as previously described.note The CA II protein was expressed and purified as previously described. ${ }^{22}$ In brief, SPR dose-response experiments were performed at $25^{\circ} \mathrm{C}$. Fresh $100 \mathrm{mM}$ DMSO fragment solutions were diluted directly with the fragment binding buffer to a final concentration of $200 \mu \mathrm{M}$ and then diluted to $12.5 \mu \mathrm{M}$ aiming for a 5-point concentration series range for the SPR dose-response experiment. Each compound was injected for $30 \mathrm{~s}$ association and $60 \mathrm{~s}$ dissociation. Scrubber 2 (www.biologic.com.au) and Microsoft Excel software packages were utilised for data processing and analysis. ${ }^{74}$ To determine $\mathrm{K}_{\mathrm{D}}$ values from dose-response experiments, binding responses at equilibrium were fit to a 1:1 steady state affinity model available within Scrubber.

\section{Protein X-ray Crystallography.}

Concentrated CA II at $\sim 10 \mathrm{mg} \mathrm{mL}^{-1}$ was set up in SD-2 plates (Molecular Dimensions) with the following ratio of protein plus reservoir plus seeds: $250 \mathrm{~nL}+225 \mathrm{~nL}+25 \mathrm{~nL}$. The plate was incubated at $8{ }^{\circ} \mathrm{C}$ and the reservoir condition consisted of $2.9 \mathrm{M}\left(\mathrm{NH}_{4}\right)_{2} \mathrm{SO}_{4}$ sulfate with 0.1 M Tris buffer at pH 8.3. Dry compound was added to the crystallisation drop after crystals had formed and several days before data were collected. 360 frames of one degree oscillation were taken at the MX-1 beamline of the Australian Synchrotron. The data were indexed using 
$\mathrm{XDS}^{75}$ and scaled using Aimless. ${ }^{76}$ Molecular replacement was done using Phaser ${ }^{77}$ using $4 \mathrm{cq} 0$ as the initial starting model. The model was manually rebuilt using $\operatorname{Coot}^{78}$ and refined using Refmac. ${ }^{79}$ The compound was placed in density using the program Afitt (OpenEye Scientific Software) and further refined using Refmac. ${ }^{79}$ The structure and structure factors were deposited in the PDB with accession codes: 5TXY, 5TY8, 5TY9, 5TYA, 5U0D, 5U0E, 5U0F, 5U0G and 5VGY.

Crystals with compound $\mathbf{1 0}$ (PDB code 5TXY) were generated by co-crystallisation. For these crystals, a six molar excess of compound to protein was added prior to the protein being set up in crystallisation trials. The data were processed as above, but Phenix ${ }^{80}$ was used to refine the structure. eLBOW ${ }^{81}$ was used to generate the cif dictionary file and the ligand was manually placed into density.

\section{Corresponding author}

S.-A.P. Telephone: +61 73735 7825; e-mail: s.poulsen@griffith.edu.au

T.S.P. Telephone: +61 39662 7304; e-mail: tom.peat@ csiro.au

\section{Acknowledgement}

This research was financed by the Australian Research Council (Grant numbers DP140101495, FT10100185). We thank Griffith University for PhD Scholarship to P.M. cDNA for CA II was kindly provided by C. Fierke. We thank OpenEye Scientific Software for a license to use Afitt, the CSIRO Collaborative Crystallisation Centre (www.csiro.au/c3) for crystallisation, and the Australian Synchrotron and the beamline scientists at the MX-1 beamline for their support in data collection. We thank J. Bentley for help with protein purification, M. Hattarki for SPR 
technical assistance, J. Ryan and T. Nebl for chemistry and mass spectrometry advice. We thank Compounds Australia staff for assistance in the production of assay-ready microplates (www.compoundsaustralia.com).

\section{Abbreviations Used}

FBDD, fragment based drug discovery; CA, carbonic anhydrase; CSIRO, Commonwealth Scientific and Industrial Research Organisation; HTS, high throughput screening; $K_{\mathrm{D}}$, dissociation constant; SPR, surface plasmon resonance; MS, mass spectrometry; $\mathrm{FA}_{M S}$, Fragment Affinity by mass spectrometry; FDA, food and drug administration; HEPES, 4-(2hydroxyethyl)-1-piperazineethanesulfonic acid; PBS, phosphate buffered saline; XRC, X-ray crystallography

Supporting Information. Data collection and structure refinement statistics of fragment:hCA II crystal structures, NMR spectra and SPR sensorgrams for compounds. This material is available free of charge via the Internet at http://pubs.acs.org.

PDB ID Codes. All of the coordinates and structure factors have been deposited in the PDB and are available with the following codes: 5TXY, 5TY8, 5TY9, 5TYA, 5U0D, 5U0E, 5U0F, 5U0G, 5VGY.

\section{References}




\section{Table of Contents Graphic}

1. Rouffet, M.; Cohen, S. M. Emerging trends in metalloprotein inhibition. Dalton Trans 2011, 40, 3445-54.

2. Anzellotti, A. I.; Farrell, N. P. Zinc metalloproteins as medicinal targets. Chem Soc Rev 2008, 37, 1629-51.

3. Supuran, C. T. Carbonic anhydrase inhibitors in the treatment and prophylaxis of obesity. Expert Opin. Ther. Patents 2003, 13, 1545-1550.

4. Bull, S.; Loudon, M.; Francis, J. M.; Joseph, J.; Gerry, S.; Karamitsos, T. D.; Prendergast, B. D.; Banning, A. P.; Neubauer, S.; Myerson, S. G. A prospective, double-blind, randomized controlled trial of the angiotensin-converting enzyme inhibitor Ramipril In Aortic Stenosis (RIAS trial). Eur Heart J Cardiovasc Imaging 2015, 16, 834-41.

5. Paris, M.; Porcelloni, M.; Binaschi, M.; Fattori, D. Histone deacetylase inhibitors: from bench to clinic. J Med Chem 2008, 51, 1505-29.

6. Fernandez-Montero, J. V.; Vispo, E.; Soriano, V. Emerging antiretroviral drugs. Expert Opin Pharmacother 2014, 15, 211-9.

7. Zastrow, M. L.; Pecoraro, V. L. Designing Hydrolytic Zinc Metalloenzymes. Biochemistry 2014, 53, 957-978.

8. Andreini, C.; Banci, L.; Bertini, I.; Rosato, A. Counting the zinc-proteins encoded in the human genome. J Proteome Res 2006, 5, 196-201.

9. Martin, D. P.; Blachly, P. G.; McCammon, J. A.; Cohen, S. M. Exploring the influence of the protein environment on metal-binding pharmacophores. J Med Chem 2014, 57, 7126-35.

10. Zhang, X. X.; Liao, C. Perspectives in Medicinal Chemistry: Metalloprotein Inhibitors: What Have We Made and What is the Next Step? Curr Top Med Chem 2016, 16, 467-9.

11. Yang, Y.; Hu, X. Q.; Li, Q. S.; Zhang, X. X.; Ruan, B. F.; Xu, J.; Liao, C. Metalloprotein Inhibitors for the Treatment of Human Diseases. Curr Top Med Chem 2016, 16, 384-96.

12. Jacobsen, J.; Fullagar, J.; Miller, M.; Cohen, S. Identifying Chelators for Metalloprotein Inhibitors Using a Fragment-Based Approach. J. Med. Chem. 2011, 54, 591-602.

13. Dupont, C. L.; Yang, S.; Palenik, B.; Bourne, P. E. Modern proteomes contain putative imprints of ancient shifts in trace metal geochemistry. Proc Natl Acad Sci U S A 2006, 103, 17822-7.

14. Kawai, K.; Nagata, N. Metal-ligand interactions: an analysis of zinc binding groups using the Protein Data Bank. Eur. J. Med. Chem. 2012, 51, 271-276.

15. Scott, D. E.; Coyne, A. G.; Hudson, S. A.; Abell, C. Fragment-Based Approaches in Drug Discovery and Chemical Biology. Biochemistry 2012, 51, 4990-5003.

16. Erlanson, D. A.; Fesik, S. W.; Hubbard, R. E.; Jahnke, W.; Jhoti, H. Twenty years on: the impact of fragments on drug discovery. Nat. Rev. Drug Discov. 2016, 15, 605-619.

17. Agrawal, A.; Johnson, S. L.; Jacobsen, J. A.; Miller, M. T.; Chen, L.-H.; Pellecchia, M.; Cohen, S. M. Chelator fragment libraries for targeting metalloproteinases. ChemMedChem 2010, 5, 195-199.

18. Credille, C. V.; Chen, Y.; Cohen, S. M. Fragment-Based Identification of Influenza Endonuclease Inhibitors. J. Med. Chem. 2016, 59, 6444-6454.

19. Wischeler, J.; Innocenti, A.; Vullo, D.; Agrawal, A.; Cohen, S.; Heine, A.; Supuran, C.; Klebe, G. Bidentate Zinc Chelators for a-Carbonic Anhydrases that Produce a Trigonal Bipyramidal Coordination Geometry. ChemMedChem 2010, 5, 1609-1615. 
20. Maresca, A.; Temperini, C.; Vu, H.; Pham, N. B.; Poulsen, S.-A.; Scozzafava, A.; Quinn, R. J.; Supuran, C. T. Non-zinc mediated inhibition of carbonic anhydrases: Coumarins are a new class of suicide inhibitors. J. Am. Chem. Soc. 2009, 131, 3057-3062.

21. Davis, R. A.; Vullo, D.; Maresca, A.; Supuran, C. T.; Poulsen, S.-A. Natural product coumarins that inhibit human carbonic anhydrases. Bioorg. Med. Chem. 2013, 21, 1539-1543.

22. Moeker, J.; Peat, T. S.; Bornaghi, L. F.; Vullo, D.; Supuran, C. T.; Poulsen, S.-A. Cyclic Secondary Sulfonamides: Unusually Good Inhibitors of Cancer-Related Carbonic Anhydrase Enzymes. J. Med. Chem. 2014, 57, 3522-3531.

23. Poulsen, S.-A. Direct screening of a dynamic combinatorial library using mass spectrometry. J. Am. Soc. Mass Spectrom. 2006, 17, 1074-1080.

24. Kopecka, J.; Rankin, G. M.; Salaroglio, I. C.; Poulsen, S. A.; Riganti, C. P-glycoproteinmediated chemoresistance is reversed by carbonic anhydrase XII inhibitors. Oncotarget 2016, 7, 85861-85875.

25. Supuran, C. T. Carbonic anhydrases: novel therapeutic applications for inhibitors and activators. Nat. Rev. Drug Discov. 2008, 7, 168-181.

26. Parks, S. K.; Cormerais, Y.; Durivault, J.; Pouyssegur, J. Genetic disruption of the pHiregulating proteins $\mathrm{Na}+\mathrm{H}+$ exchanger 1 (SLC9A1) and carbonic anhydrase 9 severely reduces growth of colon cancer cells. Oncotarget 2016, in press.

27. Poulsen, S. Carbonic anhydrase inhibition as a cancer therapy: a review of patent literature, 2007-2009. Expert Opin. Ther. Patents 2010, 20, 795-806.

28. Mujumdar, P.; Teruya, K.; Tonissen, K.; Vullo, D.; Supuran, C.; Peat, T.; Poulsen, S.A. An Unusual Natural Product Primary Sulfonamide: Synthesis, Carbonic Anhydrase Inhibition, and Protein X-ray Structures of Psammaplin C. J. Med. Chem. 2016, 59.

29. Woods, L.; Dolezal, O.; Ren, B.; Ryan, J.; Peat, T.; Poulsen, S. Native State Mass Spectrometry, Surface Plasmon Resonance, and X-ray Crystallography Correlate Strongly as a Fragment Screening Combination. J. Med. Chem. 2016, 59, 2192-2204.

30. Ryde, U. Carboxylate binding modes in zinc proteins: a theoretical study. Biophys $J$ 1999, 77, 2777-87.

31. Jacobsen, J. A.; Major Jourden, J. L.; Miller, M. T.; Cohen, S. M. To bind zinc or not to bind zinc: an examination of innovative approaches to improved metalloproteinase inhibition. Biochim Biophys Acta 2010, 1803, 72-94.

32. Liang, J.; Lipscomb, W. N. Binding of sulfonamide and acetamide to the active-site Zn2+ in carbonic anhydrase: a theoretical study. Biochemistry 1989, 28, 9724-33.

33. Boriack, P. A.; Christianson, D. W.; Kingery-Wood, J.; Whitesides, G. M. Secondary interactions significantly removed from the sulfonamide binding pocket of carbonic anhydrase II influence inhibitor binding constants. J Med Chem 1995, 38, 2286-91.

34. Martin, D.; Hann, Z.; Cohen, S. Metalloprotein-Inhibitor Binding: Human Carbonic Anhydrase II as a Model for Probing Metal-Ligand Interactions in a Metalloprotein Active Site. Inorganic Chemistry 2013, 52, 12207-12215.

35. Swayze, E. E.; Jefferson, E. A.; Sannes-Lowery, K. A.; Blyn, L. B.; Risen, L. M.; Arakawa, S.; Osgood, S. A.; Hofstadler, S. A.; Griffey, R. H. SAR by MS: a ligand based technique for drug lead discovery against structured RNA targets. J. Med. Chem. 2002, 45, 3816-9.

36. Alterio, V.; Di Fiore, A.; D’Ambrosio, K.; Supuran, C. T.; De Simone, G. Multiple binding modes of inhibitors to carbonic anhydrases: How to design specific drugs targeting 15 different isoforms? Chem. Rev. 2012, 112, 4421-4468.

37. Lipinski, C.; Fiese, E. F.; Korst, R. J. pKa, Log P and MedChem CLOGP fragment values of acidic heterocyclic potential bioisosteres. Quant. Struct.-Act. Relat. 1991, 10, 109117. 
38. Liu, W.; Lau, F.; Liu, K.; Wood, H. B.; Zhou, G.; Chen, Y.; Li, Y.; Akiyama, T. E.; Castriota, G.; Einstein, M.; Wang, C.; McCann, M. E.; Doebber, T. W.; Wu, M.; Chang, C. H.; McNamara, L.; McKeever, B.; Mosley, R. T.; Berger, J. P.; Meinke, P. T. Benzimidazolones: A New Class of Selective Peroxisome Proliferator Activated Receptor $\gamma$ (PPAR $\gamma$ ) Modulators. J. Med. Chem. 2011, 54, 8541-8554.

39. Hofstadler, S. A.; Sannes-Lowery, K. A. Applications of ESI-MS in drug discovery: interrogation of noncovalent complexes. Nat. Rev. Drug Discov. 2006, 5, 585-595.

40. Leney, A. C.; Heck, A. J. R. Native Mass Spectrometry: What is in the Name? J. . Am. Soc. Mass Spectrom. 2017, 28, 5-13.

41. Vivat-Hannah, V.; Atmanene, C.; Zeyer, D.; Van Dorsselaer, A.; Sanglier-Cianférani, S. Native MS: an 'ESI, way to support structure - and fragment-based drug discovery. Future Med. Chem. 2010, 2, 35-50.

42. Maple, H. J.; Garlish, R. A.; Rigau-Roca, L.; Porter, J.; Whitcombe, I.; Prosser, C. E.; Kennedy, J.; Henry, A. j.; Taylor, R. J.; Crump, M. P.; Crosby, J. Automated Protein-Ligand Interaction Screening by Mass Spectrometry. J. Med. Chem. 2012, 55, 837-851.

43. Drinkwater, N.; Vu, H.; Lovell, K. M.; Criscione, K. R.; Collins, B. M.; Prisinzano, T. E.; Poulsen, S.-A.; McLeish, M. J.; Grunewald, G. L.; Martin, J. L. Fragment-based screening by X-ray crystallography, MS and isothermal titration calorimetry to identify PNMT (phenylethanolamine N-methyltransferase) inhibitors Biochem. J. 2010, 431, 51-61.

44. Poulsen, S.-A. Fragment Screening by Native State Mass Spectrometry. Aust. J. Chem. 2013, 66, 1495-1501.

45. Pedro, L.; Quinn, R. J. Native Mass Spectrometry in Fragment-Based Drug Discovery. Molecules 2016, $21,984$.

46. Hulme, E. C.; Trevethick, M. A. Ligand binding assays at equilibrium: validation and interpretation. Br J Pharmacol 2010, 161, 1219-37.

47. Ermolenko, L.; Zhaoyu, H.; Lejeune, C.; Vergne, C.; Ratinaud, C.; Nguyen, T. B.; AlMourabit, A. Concise synthesis of Didebromohamacanthin A and Demethylaplysinopsine: Addition of Ethylenediamine and Guanidine Derivatives to the Pyrrole-Amino Acid Diketopiperazines in Oxidative Conditions. Org. Lett. 2014, 16, 872-875.

48. Baell, J. B.; Holloway, G. A. New Substructure Filters for Removal of Pan Assay Interference Compounds (PAINS) from Screening Libraries and for Their Exclusion in Bioassays. J. Med. Chem. 2010, 53, 2719-2740.

49. Oikonomakos, N. G., Skamnaki, V.T., Osz, E., Szilagyi, L., Somsak, L., Docsa, T., Toth, B., Gergely, P. Kinetic and crystallographic studies of glucopyranosylidene spirothiohydantoin binding to glycogen phosphorylase B. bioorg Med Chem 2002, 10, 261-268. 50. Zidar, N.; Tomasic, T.; Sink, R.; Rupnik, V.; Kovac, A.; Turk, S.; Patin, D.; Blanot, D.; Contreras Martel, C.; Dessen, A.; Muller Premru, M.; Zega, A.; Gobec, S.; Peterlin Masic, L.; Kikelj, D. Discovery of novel 5-benzylidenerhodanine and 5-benzylidenethiazolidine-2,4dione inhibitors of MurD ligase. J. Med. Chem. 2010, 53, 6584-94.

51. Tomasic, T.; Zidar, N.; Sink, R.; Kovac, A.; Blanot, D.; Contreras-Martel, C.; Dessen, A.; Muller-Premru, M.; Zega, A.; Gobec, S.; Kikelj, D.; Masic, L. P. Structure-based design of a new series of D-glutamic acid based inhibitors of bacterial UDP-N-acetylmuramoyl-Lalanine:D-glutamate ligase (MurD). J. Med. Chem. 2011, 54, 4600-10.

52. Tomasic, T., Sink, R., Zidar, N., Fic, A., Contreras-Martel, C., Dessen, A., Patten, D., Blanot, D., Muller-Premru, M., Gobec, S., Zega, A., Kikelj, D., and Masic, L. P. . Dual Inhibitor of MurD and MurE Ligases from Escherichia coli and Staphylococcus aureus. ACSMed.Chem.Lett. 2012, 3, 626-630.

53. Nolte, R. T.; Wisely, G. B.; Westin, S.; Cobb, J. E.; Lambert, M. H.; Kurokawa, R.; Rosenfeld, M. G.; Willson, T. M.; Glass, C. K.; Milburn, M. V. Ligand binding and co-activator assembly of the peroxisome proliferator-activated receptor-gamma. Nature 1998, 395, 137-43. 
54. Binda, C.; Aldeco, M.; Geldenhuys, W. J.; Tortorici, M.; Mattevi, A.; Edmondson, D. E. Molecular Insights into Human Monoamine Oxidase B Inhibition by the Glitazone AntiDiabetes Drugs. ACS Med Chem Lett 2011, 3, 39-42.

55. Good, A. C.; Liu, J.; Hirth, B.; Asmussen, G.; Xiang, Y.; Biemann, H. P.; Bishop, K. A.; Fremgen, T.; Fitzgerald, M.; Gladysheva, T.; Jain, A.; Jancsics, K.; Metz, M.; Papoulis, A.; Skerlj, R.; Stepp, J. D.; Wei, R. R. Implications of promiscuous Pim-1 kinase fragment inhibitor hydrophobic interactions for fragment-based drug design. J. Med. Chem. 2012, 55, 2641-8.

56. Hughes, S. J.; Millan, D. S.; Kilty, I. C.; Lewthwaite, R. A.; Mathias, J. P.; O'Reilly, M. A.; Pannifer, A.; Phelan, A.; Stuhmeier, F.; Baldock, D. A.; Brown, D. G. Fragment based discovery of a novel and selective PI3 kinase inhibitor. Bioorg. Med. Chem. Lett. 2011, 21, 6586-90.

57. Dakin, L. A.; Block, M. H.; Chen, H.; Code, E.; Dowling, J. E.; Feng, X.; Ferguson, A. D.; Green, I.; Hird, A. W.; Howard, T.; Keeton, E. K.; Lamb, M. L.; Lyne, P. D.; Pollard, H.; Read, J.; Wu, A. J.; Zhang, T.; Zheng, X. Discovery of novel benzylidene-1,3-thiazolidine-2,4diones as potent and selective inhibitors of the PIM-1, PIM-2, and PIM-3 protein kinases. Bioorg. Med. Chem. Lett. 2012, 22, 4599-604.

58. Camps, M.; Ruckle, T.; Ji, H.; Ardissone, V.; Rintelen, F.; Shaw, J.; Ferrandi, C.; Chabert, C.; Gillieron, C.; Francon, B.; Martin, T.; Gretener, D.; Perrin, D.; Leroy, D.; Vitte, P. A.; Hirsch, E.; Wymann, M. P.; Cirillo, R.; Schwarz, M. K.; Rommel, C. Blockade of PI3Kgamma suppresses joint inflammation and damage in mouse models of rheumatoid arthritis. Nature medicine 2005, 11, 936-43.

59. Richardson, C. M.; Nunns, C. L.; Williamson, D. S.; Parratt, M. J.; Dokurno, P.; Howes, R.; Borgognoni, J.; Drysdale, M. J.; Finch, H.; Hubbard, R. E.; Jackson, P. S.; Kierstan, P.; Lentzen, G.; Moore, J. D.; Murray, J. B.; Simmonite, H.; Surgenor, A. E.; Torrance, C. J. Discovery of a potent CDK2 inhibitor with a novel binding mode, using virtual screening and initial, structure-guided lead scoping. Bioorg. Med. Chem. Lett. 2007, 17, 3880-5.

60. Zidar, N.; Tomasic, T.; Sink, R.; Kovac, A.; Patin, D.; Blanot, D.; Contreras-Martel, C.; Dessen, A.; Premru, M. M.; Zega, A.; Gobec, S.; Masic, L. P.; Kikelj, D. New 5benzylidenethiazolidin-4-one inhibitors of bacterial MurD ligase: design, synthesis, crystal structures, and biological evaluation. Eur J Med Chem 2011, 46, 5512-23.

61. Gillilan, R. E.; Ayers, S. D.; Noy, N. Structural basis for activation of fatty acid-binding protein 4. J Mol Biol 2007, 372, 1246-60.

62. Yu, W.; Guo, Z.; Orth, P.; Madison, V.; Chen, L.; Dai, C.; Feltz, R. J.; Girijavallabhan, V. M.; Kim, S. H.; Kozlowski, J. A.; Lavey, B. J.; Li, D.; Lundell, D.; Niu, X.; Piwinski, J. J.; Popovici-Muller, J.; Rizvi, R.; Rosner, K. E.; Shankar, B. B.; Shih, N.-Y.; Arshad Siddiqui, M.; Sun, J.; Tong, L.; Umland, S.; Wong, M. K. C.; Yang, D.-y.; Zhou, G. Discovery and SAR of hydantoin TACE inhibitors. Bioorganic \& medicinal chemistry letters 2010, 20, 1877-1880.

63. Yu, W.; Tong, L.; Kim, S. H.; Wong, M. K.; Chen, L.; Yang, D. Y.; Shankar, B. B.; Lavey, B. J.; Zhou, G.; Kosinski, A.; Rizvi, R.; Li, D.; Feltz, R. J.; Piwinski, J. J.; Rosner, K. E.; Shih, N. Y.; Siddiqui, M. A.; Guo, Z.; Orth, P.; Shah, H.; Sun, J.; Umland, S.; Lundell, D. J.; Niu, X.; Kozlowski, J. A. Biaryl substituted hydantoin compounds as TACE inhibitors. Bioorg. Med. Chem. Lett. 2010, 20, 5286-9.

64. Durham, T. B.; Klimkowski, V. J.; Rito, C. J.; Marimuthu, J.; Toth, J. L.; Liu, C.; Durbin, J. D.; Stout, S. L.; Adams, L.; Swearingen, C.; Lin, C.; Chambers, M. G.; Thirunavukkarasu, K.; Wiley, M. R. Identification of potent and selective hydantoin inhibitors of aggrecanase- 1 and aggrecanase- 2 that are efficacious in both chemical and surgical models of osteoarthritis. J. Med. Chem. 2014, 57, 10476-85.

65. De Savi, C.; Waterson, D.; Pape, A.; Lamont, S.; Hadley, E.; Mills, M.; Page, K. M.; Bowyer, J.; Maciewicz, R. A. Hydantoin based inhibitors of MMP13--discovery of AZD6605. Bioorg. Med. Chem. Lett. 2013, 23, 4705-12. 
66. Francesco, I. N.; Wagner, A.; Colobert, F. Suzuki-Miyaura Coupling Reaction of Boronic Acids and Ethyl Glyoxylate: Synthetic Access to Mandelate Derivatives. Eur. J. Org. Chem. 2008, 5692-5695.

67. Sheehan, J. C.; Laubach, G. D. The Synthesis of Substituted Penicillins and Simpler Structural Analogs. V. The Application of 5-Phenyloxazolidine-2,4-diones to the Synthesis of Phenylacetylamino- $\beta$-lactams. J. Am. Chem. Soc. 1951, 73, 4752-4755.

68. Al-Horani, R. A.; Desai, U. R. Electronically rich N-substituted tetrahydroisoquinoline 3-carboxylic acid esters: concise synthesis and conformational studies. Tetrahedron 2012, 68, 2027-2040.

69. Tang, S. Q.; Lee, Y. Y. I.; Packiaraj, D. S.; Ho, H. K.; Chai, C. L. L. Systematic Evaluation of the Metabolism and Toxicity of Thiazolidinone and Imidazolidinone Heterocycles. Chem. Res. Toxicol. 2015, 28, 2019-2033.

70. Kottakota, S. K.; Benton, M.; Evangelopoulos, D.; Guzman, J. D.; Bhakta, S.; McHugh, T. D.; Gray, M.; Groundwater, P. W.; Marrs, E. C. L.; Perry, J. D.; Harburn, J. J. Versatile routes to marine sponge metabolites through benzylidene rhodanines. Org. Lett. 2012, 14, 63106313.

71. Giles, R. G.; Lewis, N. J.; Quick, J. K.; Sasse, M. J.; Urquhart, M. W. J.; Youssef, L. Regiospecific Reduction of 5-Benzylidene-2,4-Thiazolidinediones and 4-Oxo-2thiazolidinethiones using Lithium Borohydride in Pyridine and Tetrahydrofuran. Tetrahedron 2000, 56, 4531-4537.

72. Willot, M.; Chen, J. C.; Zhu, J. Combination of Lithium Chloride and Hexafluoroisopropanol for Friedel-Crafts Reactions. Syn. Lett. 2009, 577-580.

73. Goutelle, S.; Maurin, M.; Rougier, F.; Barbaut, X.; Bourguignon, L.; Ducher, M.; Maire, P. The Hill equation: a review of its capabilities in pharmacological modelling. Fundam Clin Pharmacol 2008, 22, 633-48.

74. Papalia, G. A.; Leavitt, S.; Bynum, M. A.; Katsamba, P. S.; Wilton, R.; Qiu, H.; Steukers, M.; Wang, S.; Bindu, L.; Phogat, S.; Giannetti, A. M.; Ryan, T. E.; Pudlak, V. A.; Matusiewicz, K.; Michelson, K. M.; Nowakowski, A.; Pham-Baginski, A.; Brooks, J.; Tieman, B. C.; Bruce, B. D.; Vaughn, M.; Baksh, M.; Cho, Y. H.; deWit, M.; Smets, A.; Vandersmissen, J.; Michiels, L.; Myszka, D. G. Comparative analysis of 10 small molecules binding to carbonic anhydrase II by different investigators using Biacore technology. Anal. Biochem. 2006, 359, 94-105.

75. Kabsch, W. XDS. Acta Crystallogr. Sect. D: Biol. Crystallogr. 2010, 66, 125-132.

76. Evans, P. R. An introduction to data reduction: space-group determination, scaling and intensity statistics. Acta Crystallogr. D Biol. Crystallogr. 2011, 67, 282-292.

77. McCoy, A. J.; Grosse-Kunstleve, R. W.; Adams, P. D.; Winn, M. D.; Storoni, L. C.; Read, R. J. Phaser crystallographic software. J. Appl. Crystallogr. 2007, 40, 658-674.

78. Emsley, P.; Lohkamp, B.; Scott, W. G.; Cowtan, K. Features and development of Coot. Acta Crystallogr. D Biol. Crystallogr. 2010, 66, 486-501.

79. Murshudov, G. N.; Skubak, P.; Lebedev, A. A.; Pannu, N. S.; Steiner, R. A.; Nicholls, R. A.; Winn, M. D.; Long, F.; Vagin, A. A. REFMAC5 for the refinement of macromolecular crystal structures. Acta Crystallogr. D Biol. Crystallogr. 2011, 67, 355-367.

80. Afonine, P. V.; Grosse-Kunstleve, R. W.; Echols, N.; Headd, J. J.; Moriarty, N. W.; Mustyakimov, M.; Terwilliger, T. C.; Urzhumtsev, A.; Zwart, P. H.; Adams, P. D. Towards automated crystallographic structure refinement with phenix.refine. Acta Crystallogr. D Biol. Crystallogr. 2012, 68, 352-367.

81. Moriarty, N. W.; Grosse-Kunstleve, R. W.; Adams, P. D. Electronic Ligand Builder and Optimization Workbench (eLBOW): a tool for ligand coordinate and restraint generation. Acta Crystallogr. D 2009, 65, 1074-1080. 